WHOI-89-36

CRC-89-6

\title{
Toxic Dinoflagellates and Marine Mammal Mortalities \\ Proceedings of an Expert Consultation held at the \\ Woods Hole Oceanographic Institution
}

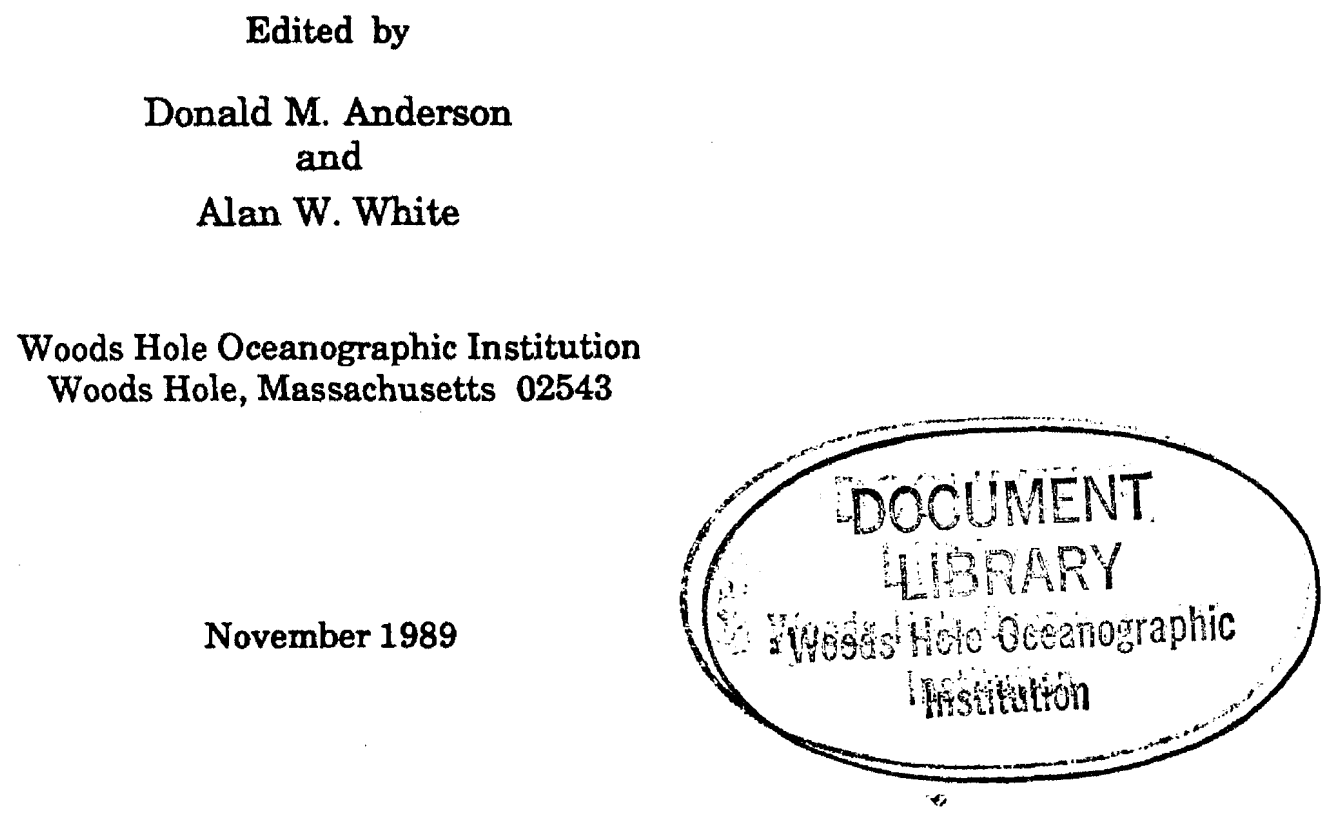

\section{Technical Report}

Funding was provided by NOAA, National Marine Fisheries Service, Woods Hole Oceanographic Institution Coastal Research Center through a grant from the Andrew W. Mellon Foundation and the Woods Hole Oceanographic Institution Sea Grant Program under Grant NA86-D-SG090 (Project R/B - 92 and M/O-2).

Reproduction in whole or in part is permitted for any purpose of the United States Government. This report should be cited as:

Woods Hole Oceanog. Inst. Tech. Rept.,

WHOI-89-36 (CRC-89-6).

Approved for publication; distribution unlimited.

Approved for Distribution:

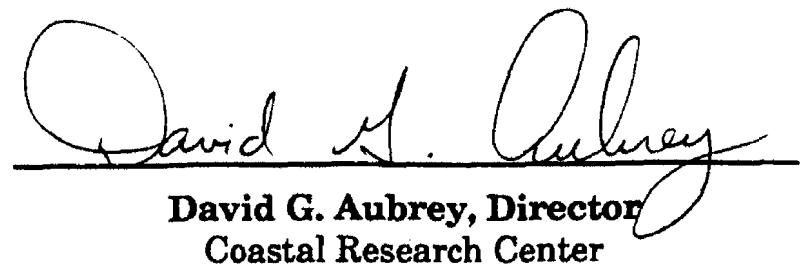




\section{Toxic Dinoflagellates and Marine Mammal MORTALITIES}

\section{TABLE OF CONTENTS}

EXECUTIVE SUMMARY

Page

I INTRODUCTION

II DINOFLAGELLATE TOXINS: SOURCE ORGANISMS AND FOOD WEB TRANSFER

A. Northeast Region

B. Southeast Region

C. Food Web Transfer

III MARINE MAMMAL MORTALITY

A. Whales

1. Epidemiology and Pathology

2. Toxin Assays

3. Potential Interactions

4. Implications

B. Dolphins

1. Epidemiology and Pathology

2. Toxin Assays

3. Potential Interactions

4. Implications

IV SEAFOOD SAFETY $\quad 25$

A. Summary of Dinoflagellate Toxins in Fish 25

B. Human and Animal Concerns 26

1. Whole Fish Uses

2. Other Fish Products

V RESEARCH AND MONITORING PRIORITIES

A. Whale Mortalities $\quad 28$

B. Dolphin Mortalities $\quad 29$

C. Seafood Safety 31

VI RECOMMENDATIONS

$\begin{array}{ll}\text { ACKNOWLEDGMENTS } & 33\end{array}$

$\begin{array}{ll}\text { REFERENCES } & 34\end{array}$ 
1. Participants List 38

2. Beached Animal Protocol 40

3. Technical Contributions 41

a. (Yuzuru Shimizu) Isolation and Identification of Saxitoxin from the 42 Atlantic Mackerel, Scomber scombrus L.

b. (K. Haya et al.) Identification of Paralytic Shellfish Toxins in Mackerel 45 from Southwest Bay of Fundy, Canada

c. (Daniel G. Baden) Brevetoxin Analysis 47

d. (Robert J. Hofman) Possible Impacts of Marine Biotoxins on Marine 53 Mammals

e. (Karen A. Steidinger) Implications of 1986-87 Ptychodiscus brevis 56 Red Tide and 1987-88 Mass Bottlenose Dolphin Mortalities 


\section{EXECUTIVE SUMMARY}

On May 8 and 9, 1989, a consultation of experts was convened at the Woods Hole Oceanographic Institution to discuss the possible link between natural biotoxins and recent mass mortalities of humpback whales and bottlenose dolphins along the eastern coast of the United States. The focus was on the possible role of dinoflagellate toxins in these events. The objectives of the meeting were to review and assess the existing evidence and to recommend research priorities and needs.

Humpback Whale Mortalities

As a result of the humpback whale deaths and the many chemical analyses of mackerel (Scomber scombrus ), a major food source of humpbacks in Massachusetts Bay in late 1987, it is now clear that living mackerel can contain the neurotoxin saxitoxin, predominantly in the liver. New evidence indicates that other derivatives of saxitoxin are present in mackerel liver at certain times of the year, and that virtually all Atlantic mackerel tested from the northeast region had detectable levels of the toxin in their viscera. The body burdens of toxin are in the range measured in other fish species taken from natural kills. Calculations suggest that whales feeding on toxic mackerel could have obtained doses in the range that might cause either direct mortality or partial incapacitation leading to mortality. At present, circumstantial evidence supports this scenario, but other explanations should not to be ignored.

\section{Dolphin Mortalities}

No single pathological disorder could be identified as common to all dead dolphins. A compound equivalent to, or at least structurally and functionally similar to, the dinoflagellate neurotoxin brevetoxin was found in the livers of some dolphins that died during the 1987 mortality event. Analyses of several specimens of wild-caught menhaden and specimens from dolphin stomachs also contained a brevetoxin-like compound. One hypothesis is that brevetoxin in food fish instigated the mass mortality by reducing dolphin physiological fitness and thus increasing their susceptibility to secondary microbiological insults. Evidence for this scenario is circumstantial and other explanations are possible. No clear alternatives have yet been proposed. 


\section{Seafood Safety}

All evidence indicates that fish contamination by either the saxitoxins or the brevetoxins is confined to viscera and that flesh is consistently non-toxic. Thus the only seafood safety concerns would be related to human consumption of whole fish or particular internal organs (as is the custom among certain ethnic groups), or perhaps in seafood products such as fish meal or oil. However, because of the processing methods used, the dilution by other non-toxic fish tissues, and the historical absence of unexplained mortalities at zoos and aquaria, it is unlikely that these products pose a health risk to humans or other animals.

\section{$\underline{\text { Recommendations }}$}

The information presently available has sufficient implications with respect to marine mammal mortalities, commercial fisheries, and public health to justify further investigations into the impact of dinoflagellate toxins on higher trophic levels. A series of research and monitoring programs is suggested. 


\section{INTRODUCTION}

Marine mammal mortalities generally occur as isolated, individual events. Occasionally, large-scale mortalities occur. There have been several reports of large-scale seal mortalities associated with viral infections (Geraci et al., 1982; Laws and Taylor, 1957; Osterhaus and Vedder, 1988). There also have been two reported incidents of major mortality events associated with biotoxins; one involving the Hawaiian monk seal (Gilmartin, 1987) and one involving the Florida manatee (O'Shea and Rathbun, 1982). To date, however, there have been no reports of large-scale cetacean mortalities other than those associated with the as yet unexplained mass stranding phenomenon of certain species of odontocetes (Geraci, 1978).

Two events in 1987-88 involved unprecedented mortalities of humpback whales and bottlenose dolphins, species that have never been associated with typical mass strandings. Moreover, the features of these events did not resemble recognized epizootics of infectious diseases in other marine mammals. The mortality of dolphins that began in the summer of 1987 along the Atlantic coast of New Jersey and continued along the Atlantic seaboard for 11 months was an unprecedented event with respect to the number of animals that eventually died (at least 740) and the lack of a single pattern of illness that could be associated with a known pathogen (Geraci, 1989). The humpback whale group mortality in late 1987 in Massachusetts and Cape Cod Bays (14 animals in less than 5 weeks) was also a unique event with respect to the number of whales recovered in such a short time span. The unusual characteristics of these two events were such that standard protocols for examining stranded animals were expanded to include analysis for dinoflagellate neurotoxins that have in the past been associated with mass kills of fish and other marine animals. 


\section{DINOFLAGELLATE TOXINS: SOURCE ORGANISMS AND FOOD WEB TRANSFER}

\section{A. Northeast Region}

Along the northeast U.S. and Canadian coastline, the dominant toxin-producing organisms are the closely-related species Alexandrium fundyense and A. tamarense (formerly called Gonyaulax tamarensis or Protogonyaulax tamarensis ). These organisms occur from the Gulf of St. Lawrence south to Long Island. In southern localities (from Cape Cod to Long Island) the toxic blooms are largely confined to small estuaries and coastal embayments and are virtually absent from nearshore coastal waters. These localized blooms in the south presumably have little or no impact on commercial finfish and thus will not be discussed further.

Alexandrium fundyense and $A$. tamarense produce a family of neurotoxins collectively called the saxitoxins (STX). The predominant problem associated with these toxins is paralytic shellfish poisoning (PSP) which occurs when shellfish filter the dinoflagellate cells from the water, accumulating the toxin to levels which are dangerous to human consumers. Another problem that is less severe within the region is that of fish kills, which have been linked to the presence of saxitoxin in zooplankton (White, 1984). It is commonly assumed that toxin exposure comes primarily through direct ingestion of either the dinoflagellate or its zooplankton predators by shellfish and fish, although the ecological significance of toxin that leaks into the seawater or that is present as an aerosol is not known.

The geographic distribution of Alexandrium spp. can be conveniently described with reference to three regions:

The Gulf of St. Lawrence. The bulk of the information from this region is in the form of shellfish toxicity records (Prakash et al., 1971) although studies describing the dinoflagellate distribution are now appearing (Therriault et al., 1985; Cembella et al., 1988). Shellfish toxicity typically has one major annual peak in July, August or September (Prakash et al., 1971). Outbreaks occasionally occur as early as June or as late as October. The western edge of the 
region of toxicity extends well into the St. Lawrence Estuary to the Manicouagan and Aux Outardes Rivers. To the east, toxicity follows a pattern that traces the plume of these rivers as it joins the Gaspe current and travels to the east along the southern shores of the St. Lawrence. Toxicity has been detected in shellfish on Newfoundland; the geographic distribution there suggests that this originates from localized dinoflagellate populations around the island.

Bay of Fundy. Shellfish toxicity is widespread within the Bay of Fundy, but the dinoflagellates seem to be most abundant in the south-central and southwestern portions of the Bay (Martin and White, 1988). As in the St. Lawrence region, toxicity usually has an annual peak in July, August or September, although outbreaks are possible somewhat earlier and later on occasion.

Gulf of Maine. Shellfish toxicity within this region extends along virtually the entire coast of Maine, New Hampshire and northern Massachusetts. PSP monitoring programs operate from April through October, with outbreaks being most common in early to mid-summer as in the above regions. Spring and fall outbreaks also occur. The dinoflagellate populations are abundant in estuaries as well as in coastal waters, possibly associated with offshore frontal systems $20-30 \mathrm{~km}$ from shore. These offshore blooms have not been well-studied and represent an important potential source of toxin for fish.

\section{Toxin Composition}

An important aspect of toxin production by dinoflagellates in this region is that different strains of Alexandrium produce different combinations of saxitoxin (STX) and its derivatives. The suite of toxins contained in an isolate is referred to as its "toxin composition". When determined by high pressure liquid chromatography (HPLC), toxin composition provides a fingerprint to identify particular strains or populations. Within the northwest Atlantic region, it has been shown that northern strains of Alexandrium contain primarily carbamate toxins, whereas those to the south in Connecticut and Long Island contain sulfamate toxins. Since these toxins differ significantly in potency, northern isolates are far more toxic than those from the south 
(Maranda, et al., 1985). Accordingly, the concentration of dinoflagellates needed to produce dangerous levels of toxin is lowest in the north.

Toxic dinoflagellates in the genus Alexandrium are widespread irathe region between Long Island and the Gulf of St. Lawrence. In northern waters, these dinoflagellates bloom predominantly during the summer months, but spring and fall outbreaks are also possible. Shellfish toxicity records document the nearshore distribution of the cells, and some limited field studies suggest their existence $10-50 \mathrm{~km}$ offshore as well. Where available, field data indicate localized, high-density accumulations of cells (such as at fronts), as well as more widespread distributions such as those seen throughout the Bay of Fundy. Since outbreaks occur virtually every year within this large region along the northwest Atlantic, many different fish populations would be exposed to these toxins, although that exposure would be restricted to certain times of the year. It is of note that relatively little PSP toxin was detected in shellfish along the shores of the Gulf of Maine in 1987 prior to the whale mortality, although no information is available on Alexandrium bloom occurrences offshore. Toxins were present in shellfish from the St. Lawrence Estuary of Canada however.

\section{B. Southeast Region}

Florida red tides caused by the dinoflagellate Ptychodiscus brevis can cause discolored seawater, shellfish toxicity (Neurotoxic Shellfish Poisoning), fish kills, and a toxic seaspray aerosol that can irritate the eyes, nose, mouth, and throat of people in the immediate vicinity of the spray (Steidinger and Baden, 1984; Pierce, 1986). Ptychodiscus brevis is a gymnodinioid of restricted Atlantic distribution, but with conspecific representatives in the Pacific. It is known from the Gulf of Mexico (Florida, Texas, and Mexico), the North Atlantic (Florida, North Carolina, and South Carolina), the Gulf Stream, and possibly the Caribbean. P. brevis red tides in the eastern Gulf of Mexico and southeastern U.S. waters originate off west central Florida about 10 to 40 miles offshore. Initiation of red tides near shore is associated with oceanic intrusions onto the shelf (Steidinger and Haddad, 1981). They can be entrained and transported from the west coast of Florida to the east coast by Loop Current waters, which enter the Florida Straits as the Florida 
Current and eventually merge with the northerly moving Gulf Stream. Such transport is known to have occurred in the fall months of 1972 (Steidinger and Haddad, 1981), 1977 (Steidinger and Haddad, 1981), 1980 (Steidinger and Haddad, 1981), 1983 (Roberts, pers. comm.), and 1987 (Tester et al., 1988).

Ptychodiscus brevis red tides are typically seasonal in that they usually begin off the west coast of Florida in late summer/early fall and last until or through January. It takes about four weeks for an offshore red tide to develop concentrations that can cause fish kills (Roberts, 1979). In addition to transport of blooms around the Florida peninsula, Lackey (1969) and Marshall $(1980,1982)$ have reported $P$. brevis in very low concentrations $\left(<2 \mathrm{ml}^{-1}\right)$ in the Gulf Stream off the southeast U.S. coast. Driftbottle releases in waters off central west Florida from 1965 to 1968 (Williams et al., 1977) and their subsequent returns, document that surface transport from central west coast offshore and coastal waters to Florida east coast sites can be completed in as short as 7 days and often in less than one month. Also, returns of bottles from North Carolina and South Carolina in summer and fall were made in as little as 31 days during that period. Therefore, $P$. brevis, a flagellate that produces neurotoxins (Baden, 1983), can co-occur with Atlantic coast coastal and offshore dolphins. Along the west coast of Florida, reported dolphin mortalities coincident with red tide events (some lasting up to 11 months) are few (Gunter et al., 1948; Steidinger et al., 1973) and are not more numerous than dolphin mortalities over the general area of the Gulf of Mexico, e.g., 1986 and 1987 (Pierce, pers. comm.).

\section{Food Web Transfer}

It is now well recognized that the toxins of certain dinoflagellates (paralytic shellfish toxins) are routinely taken up by a variety of marine organisms during blooms and transferred to others, with mass kills of marine fish resulting in some instances. On occasion this contamination of fish has led to kills of seabirds (Adams, 1978; Nisbet, 1983), other fish (Nisbet, 1983) and, in at least one instance, of humans (Adnan, 1984). In this context, it would seem plausible that marine mammal mortalities could occur when toxic dinoflagellates and the mammals' food items overlap in time and space, as was suggested several years ago (White, 1984). Indeed, a mass kill of seals off 
the coast of South Africa in the early 1800 s appears to have been related to red tide toxins in fish (Wyatt, 1980).

Paralytic shellfish toxins have been detected in an array of marine organisms during and following Alexandrium blooms. These organisms include filter-feeding molluscs, carnivorous molluscs, crabs, starfish, barnacles, tubeworms, various zooplankton (tintinnids, copepods, cladocerans, pteropods, etc.), planktivorous fish and squid (Jonas-Davies and Liston, 1985; White, 1981a; J. Hurst, pers. comm.). In terms of their potential to serve as vectors of the toxins to marine mammals, zooplankton and planktivorous fish (such as menhaden, sand lance, herring and mackerel) are prime suspects (shellfish would be the main food web link to walruses and otters).

\section{Zooplankton}

Zooplankton have been shown to acquire the toxins on a routine basis during the annual Alexandrium blooms in the Bay of Fundy, with toxin levels often reaching about $60 \mu \mathrm{g}$ STX equiv./g wet weight plankton (White, 1984). The toxins appear to remain in the zooplankton community for only a few weeks (White, 1979), but during this period there can be repercussions in the food web. In 1976 and 1979, massive kills of adult herring occurred in the Bay of Fundy during Alexandrium blooms as a result of toxin transfer through zooplankton (White, 1980). Similar events, involving Alexandrium toxins, zooplankton and kills of sand lance occurred in England in 1968 (Adams et al., 1968) and off Cape Cod in 1978 (Nisbet, 1983). (Incidentally, as in the whale kill off Cape Cod in 1987, there were no inshore indications of an Alexandrium bloom occurring prior to or during the 1978 sand lance kill off Wellfleet). In 1979, a menhaden kill occurred in Maine during an Alexandrium bloom (J. Hurst, pers. comm.); in this instance, however, the toxins were likely transferred directly from the dinoflagellates to the fish, which are phytoplanktivores. Calculations based on oral dose responses of marine fish to the toxins suggest that at $60 \mu \mathrm{g}$ toxins/g zooplankton as little as 1 gram of zooplankton would constitute a lethal dose for a 100-g fish (White, 1981b). Experimental studies show that ingestion of zooplankton containing much less toxin than this cause mortality of marine fish larvae (White et al., 1989). It 
should be noted that zooplankton retain the same complex of toxins as in the dinoflagellates, i.e ., major conversions of the toxins do not take place (Hayashi et al., 1982).

To translate toxin levels in zooplankton to potential effects on whales, we need information on the sensitivity of whales to the toxins, which of course is lacking. The LD50s for terrestrial mammals (mice, rats, rabbits and cats) range from 200 to $600 \mu \mathrm{g} / \mathrm{kg}$ (Evans, 1972). Humans, however, appear to be much more sensitive than this; rough estimates of the minimum lethal oral dose for humans are as low as 7 to $16 \mu \mathrm{g} / \mathrm{kg}$ (Schantz et al., 1975). One would expect that lethal levels for aquatic mammals may well be lower than for terrestrial mammals because aquatic mammals must orient properly to breathe, i.e ., moderate symptoms of poisoning may lead to drowning of aquatic mammals. There are no data on the effects of long-term, sub-lethal doses of STX in humans or other animals.

Using the conservative figures, if we assume that the sensitivity of whales to the toxins is in the $200-600 \mu \mathrm{g} / \mathrm{kg}$ range, then a 30 -ton whale would have to eat about 90 to $275 \mathrm{~kg}$ of zooplankton (wet weight, and containing $60 \mu \mathrm{g}$ STX equiv./g) to obtain the LD50 dosage. This is well below the estimated amount of food that baleen whales eat daily, i.e ., about $4 \%$ of their body weight (Sergeant, 1969) or about $1,100 \mathrm{~kg}$ in this case.

\section{Fish}

Studies with herring, pollock, flounder, and salmon show that these fish are sensitive to Alexandrium toxins (White, 1981b). Their oral and intraperitoneal dose responses to the toxins are similar to those for warm-blooded animals. The oral LD50 is $400-750 \mu \mathrm{g} / \mathrm{kg}$; the i.p. LD50 is 4$12 \mu \mathrm{g} / \mathrm{kg}$. Symptoms of poisoning (disequilibrium and swimming on sides) appear within minutes of exposure to the toxins, with death occurring after 20 to $60 \mathrm{~min}$. Some fish recover from the poisoning and resume normal behavior after a few hours.

In terms of seafood safety, it is fortunate that fish, like warm-blooded vertebrates, are highly sensitive to paralytic shellfish toxins in their muscle tissues (White, 1981b). This means that fish are unable to accumulate the toxins in their flesh; they die before the toxins reach levels unsafe for 
consumers. This is corroborated by the fact that assays of flesh of fish killed by Alexandrium toxins in nature show either undetectable or very low levels of toxins (White, 1984).

However, the toxins can occur in substantial amounts in fish viscera. Toxin levels as high as $1400 \mu \mathrm{g}$ toxins $/ 100 \mathrm{~g}$ viscera have been reported (White, 1984). Past experience has shown that toxin levels in the viscera can be high enough so that ingestion of whole fish can cause kills of seabirds (Adams, 1968; Nisbet, 1983), carnivorous fish (Nisbet, 1983) and humans (Adnan, 1984). During a Pyrodinium red tide in Indonesia in 1983, 4 people were killed and 191 became ill from "paralytic shellfish poisoning" after eating whole planktivorous (clupeoid) fish taken alive from the red tide area. Similar human poisonings, without deaths, have been reported during other red tide episodes in Borneo and the Philippines (Maclean, 1989; White, 1984). An interesting note in this connection is that since the time of the Romans a paste prepared from fermented mackerel innards, called "Gentlemen's Relish," has been eaten in the United Kingdom (T. Wyatt, pers. comm.).

Toxin analyses of Atlantic mackerel caught during the humpback whale kill in late 1987 showed a mean toxin concentration of $153 \mu \mathrm{g} / 100 \mathrm{~g}$ in the livers and a total body burden of 80 $\mu \mathrm{g} / \mathrm{kg}$ (Geraci et al., in press). Similar levels of toxins, 40 to $209 \mu \mathrm{g} / 100 \mathrm{~g}$, were found in the livers of live mackerel from the Bay of Fundy in 1988 (Haya et al., 1989). In the former case, for which a figure for total body burden is available, the toxin level is within the range reported for whole, dead specimens of herring, sand lance and menhaden taken from kills, $23-970 \mu \mathrm{g} / \mathrm{kg}$ (White, 1984). Yet, the mackerel were apparently not affected -- at least not killed. This suggests that mackerel may have different sensitivity to the toxins, as perhaps does Japanese pufferfish (Fugu ) which can contain STX and tetrodotoxin in its liver and gonads (Nakamura et al., 1984). Virtually nothing is known about the fate of toxins in, or consequences to, fish when provided at sub-lethal levels over a period of time. Under these conditions, fish may be able to accumulate and store the toxins in certain organs.

How much toxin is a whale likely to acquire from eating contaminated fish? Using the figures of 23 to $970 \mu \mathrm{g}$ STX equiv./kg (White, 1984) for total body burdens of paralytic shellfish 
toxins in fish, and assuming a whale consumes $4 \%$ of its body weight per day, calculations indicate that consumption of fish at this toxin level would provide a whale with 0.9 to $39 \mu \mathrm{g}$ toxin $/ \mathrm{kg}$. This is considerably less than the $200-600 \mu \mathrm{g} / \mathrm{kg}$ oral LD50 reported for mice, rats, rabbits and cats (Evans, 1972), but it is in line with the estimated minimum lethal oral dose for humans, 7 to $16 \mu \mathrm{g} / \mathrm{kg}$ (Schantz et al., 1975).

Conclusion

The information available points to the feasibility of Alexandrium toxins being transferred through zooplankton and/or planktivorous fish to humpback whales. Assuming that whales have similar toxin sensitivity to other mammals, it appears that zooplankton (at least in the Bay of Fundy) reach toxin levels sufficient to present a danger to the whales. The data available on the toxin content of fish indicate levels that are high enough to provide tantalizing, but not compelling, circumstantial evidence that whale kills may result from eating fish. The fact that toxin-containing fish have caused kills of seabirds, other fish and humans lends credence to the notion that they can also affect whales.

To help unravel the impact of dinoflagellate toxins on marine mammals, we must know more about exposure of mackerel and other fish to sub-lethal levels of the toxins, sources of the toxins (unobserved offshore blooms, bacteria, etc.), levels of toxins that can be accumulated in living fish, whether other dinoflagellate toxins follow similar food web routes as for paralytic shellfish toxins and whether intoxicated fish may be more susceptible to predation. Investigations of marine mammal mortalities should include analyses for dinoflagellate toxins, as soon as possible after the events are observed.

\section{MARINE MAMMAL MORTALITIES}

\section{A. Whales}

\section{Epidemiology and Pathology}

During late fall, humpback whales (Megaptera novaeangliae) typically feed on sand lance (Ammodytes sp.) on Stellwagen Bank off the Massachusetts coast. However, in the fall of 1987, 
sand lance stocks were largely absent on the Bank, and humpbacks moved south towards Cape Cod, where they apparently fed on Atlantic mackerel (Scomber scombrus).

Between November 28, 1987 and January 3, 1988, 14 humpbacks were found dead along the beaches of Cape Cod Bay and northern Nantucket Sound. During the previous 10 years, a total of only 3 humpbacks were found by an organized stranding recovery network in this area.

The whales evidently died acutely in robust physical condition with ample fat reserves. No common significant pathological lesions or infectious agents of disease were found in 12 whales examined postmortem. However, in 6 of 9 whales, partially digested fish, later identified as mackerel, were found in the stomachs, a comparatively rare finding in stranded dead whales which usually have empty stomachs. Extracts of kidney, liver and stomach contents from the whales contained a potent toxin activity with properties similar to saxitoxin in mouse bioassy.

\section{Toxin Assays}

The saxitoxins are a family of compounds based on the parent compound saxitoxin (Schantz et al., 1975). Those known from the source organisms, the dinoflagellates Alexandrium spp., Gymnodinum catenatum, and Pyrodinium bahamense, include derivatives formed by the addition of N-1-hydroxyl, 11-hydroxysulfate, and 21-sulfo groups (Hall and Reichardt, 1984). These toxins act by selectively blocking the influx of sodium ions through excitable cell membranes, effectively interrupting the formation of an action potential (reviewed by Shimizu, 1987).

Methods. Toxic compounds in fish and whale samples were detected using the standard mouse bioassay (Adams and Meiscier, 1980), liquid chromatography (Sullivan et al., 1985) and single channel pharmacology (S. Hall, pers. comm.). Isolation of toxic components was performed by column chromatography using activated charcoal followed by Biogel P-2. The toxin was identified by thin layer chromatography, electrophoresis and mouse neuroblastoma cell assay (Kogure et al., 1988).

Results. After extensive analyses with all of the above methods, saxitoxin has been unequivocally identified in mackerel. The toxin was universally present in viscera, especially liver, of mackerel caught at the time and place the whales were feeding, and in others collected in the 
region north and south of the study area. Only STX was detected, and not any of its 11 derivatives. In a study by Geraci et al. (in press) five analyses of composite tissues from 17 fish collected near the time of the mortality event showed STX in liver at a mean concentration of 153 $\mu \mathrm{g} / 100 \mathrm{ug}$. Average concentration in four fish was $52.3 \mu \mathrm{g} \mathrm{STX} / 100 \mathrm{~g}$ of viscera (range 40.2$71.2 \mu \mathrm{g} / 100 \mathrm{~g}$ ), equivalent to a mean total body burden of $80 \mu \mathrm{g} \mathrm{STX/kg} \mathrm{fish.} \mathrm{No} \mathrm{toxin} \mathrm{was}$ detected in fish muscle. Pacific mackerel, Scomber japonicus, tested as a control, contained no STX.

Subsequent analyses of mackerel from a wider area (Rhode Island to the Bay of Fundy, Canada) in 1988 showed that nearly every fish tested contained some STX, with highest concentrations of over $600 \mu \mathrm{g} / 100 \mathrm{~g}$ liver (B. Learson, Y. Shimizu, J. Hurst, pers. comm.). Mackerel collected throughout the Alexandrium fundyense bloom period in the Bay of Fundy contained similar amounts of toxin to those measured at the time of the whale mortality event (40$200 \mu \mathrm{g} / 100 \mathrm{~g}$ liver, Haya et al., 1989). Analyses of these fish by HPLC revealed saxitoxin as well as several of its derivatives (B2, GTX II, GTX III, and NEO). In general, saxitoxin was the major toxin in the livers whereas GTX II, III were the major toxins in the intestines.

Exuracts from 3 of 8 humpback whale kidneys, 4 of 7 livers, and the contents from 7 of 9 stomachs (macerated flesh, bones, fluid) caused mice to die with signs characteristic of saxitoxin poisoning. Control liver samples $(n=21)$ from 4 cetacean species that died unrelated to the 1987 mass mortality showed no such toxicity. One each of the positive kidney and liver samples from the whales were re-tested by means of tissue culture assay for sodium channel blockage and shown to be positive (Y. Shimizu, pers. comm.). However, HPLC analysis showed no STX peak in these whale tissues (Geraci et al., in press).

Geraci et al. (in press) calculate that whales feeding on mackerel prior to their southward migration could have received a daily dose of saxitoxin of $3.2 \mu \mathrm{g} / \mathrm{kg}$ body weight. This is in a range similar to the minimum lethal oral dose estimated for humans $(7-16 \mu \mathrm{g} / \mathrm{kg}$; Shantz et al., 1975). Other factors that must be considered when evaluating the possible effects from this dose of saxitoxin are that the toxin might only need to incapacitate a marine mammal to have lethal 
results (i.e. loss of equilibrium, respiratory distress leading to drowning) and that the mammalian diving reflex will shunt toxins away from excretory and detoxifying organs (kidney, liver).

It is of note that metabolic processes in at least some accumulating organisms can remove the N-1-hydroxyl and 11-hydroxysulfate groups and the carbamate and sulfamate side chains from the saxitoxins (Proctor et al., 1975; Shimizu and Yoshioka, 1981; Sullivan et al., 1983). The demonstration of toxin conversion within shellfish tissue (Shimizu and Yoshioka, 1981) is relevant to the whale poisonings in that the only toxin detected by HPLC in mackerel liver during the mortality event was saxitoxin, despite the presence of many other saxitoxin derivatives in Alexandrium cells from that region (see section II A). This suggests that a conversion occurred within the mackerel tissues, there was selective retention of only saxitoxin by those tissues, or the toxin source was not Alexandrium. Subsequent HPLC analyses of Canadian mackerel tissues (Haya et al., 1989) revealed toxins in addition to saxitoxin, possibly related to the short time between fish capture and the ingestion of toxic food items by those fish.

Decarbamoylation of the toxins by shellfish (Sullivan et al., 1983) is noteworthy in light of the lack of saxitoxin peaks in HPLC analyses of whale tissues, despite the strong signs of saxitoxin-like poisoning in mice injected with those extracts and the positive results from tissue culture assay. Decarbamoylation reduces toxin potency only slightly, but does make the componds difficult to detect by the HPLC technique now in common use.

\section{Potential Interactions}

The two main food sources that would expose marine mammals to paralytic shellfish toxins are zooplankton and planktivorous fish (see Section II C). Since Alexandrium blooms are annual late spring and summer events throughout northern New England and eastern Canada, these organisms would contain the toxins seasonally at least (as shown for Bay of Fundy zooplankton) and perhaps in some instances year-round (as is suspected for Atlantic mackerel). The current evidence that the dinoflagellates contain more potent toxins in northern waters than southern (Maranda et al., 1985) suggests that zooplankton and fish feeding in these northern areas may 
acquire greater toxin loads than elsewhere in the region or may become toxic more frequently. They also might be less sensitive to the toxin as a result of this increased exposure.

Concerning the zooplankton route of toxin transvection, the only baleen whale in this region that is known to feed primarily on zooplankton is the right whale. There is a population of right whales that resides in the southern Bay of Fundy in the summer, overlapping the period of toxic dinoflagellate blooms and the period when the zooplankton community becomes contaminated with high levels of the toxins. Despite the apparent plausibility of whales being poisoned from eating toxin-containing zooplankton, no mass mortalities or unusual behavior of right whales have yet been reported. However, right whales have not been investigated in regard to this specific question, and studies here would seem worthwhile.

Shifting the focus to fish as transvectors of the toxins, Atlantic mackerel is the species of chief concern because of its implication in the 1987/88 humpback whale mortalities and because the toxins have been found in mackerel over the entire northwest Atlantic region. There is ample evidence (from literature reviews of food habits derived from stranded animals and animals taken incidentally in fisheries operations) that mackerel would interact on a temporal and spatial basis with the following marine mammals:

large whales:

minke whale

humpback whale

finback whale

small toothed whales:

pilot whale

bottlenose dolphin

harbor porpoise

white-sided dolphin

common dolphin

grey grampus 
harbor seals

grey seals

The Atlantic mackerel is a highly migratory fish. Information on its general distribution and migratory patterns may shed some light on where this stock acquires its toxin load. Atlantic mackerel are distributed between Labrador and North Carolina. There are two major spawning components of this population, a southern group, which spawns primarily in the Mid-Atlantic Bight during April and May, and a northern group, which spawns in the Gulf of St. Lawrence in June and July (Sette, 1950). Both groups overwinter between Sable Island (off Nova Scotia) and Cape Hatteras in waters generally warmer than $7^{\circ} \mathrm{C}$, with extensive northerly migrations in the spring and southerly migrations in the fall to and from spawning and summering grounds. After spawning, the southern group continues through the Gulf of Maine and summers there and in the Bay of Fundy, where fish could acquire high levels of dinoflagellate toxins. The northern group summers in the Gulf of St. Lawrence, where fish could also acquire the toxins. On their return migration in the fall, both groups pass through the waters off Cape Cod and may encounter humpback whales feeding in the that area prior to their annual migration to the Caribbean.

Besides mackerel, there are other planktivorous fishes in the Northwest Atlantic that are among the prey of marine mammals. They include sand lance, Atlantic herring, capelin, butterfish, and silver hake, as well as squid. These animals are not as migratory as mackerel. All but sand lance display a seasonal shift in distribution within the northeast region, but not the extensive north/south migration characteristic of mackerel. Sand lance occur as resident populations on Georges Bank, Stellwagen Bank, and along the southern New England shelf. Herring and sand lance are known to acquire saxitoxins; the toxins have been found in them after mass mortality events (see Section II C). Whether these and other fish can, after chronic sub-lethal exposures, retain the toxins in their internal organs, as apparently mackerel do, remains to be determined. Nothing is known about whether toxins can be present in capelin, silver hake or butterfish. The toxins have also been detected in menhaden and squid during toxic dinoflagellate blooms off Maine 
(J. Hurst, pers. comm.). Menhaden does not appear to be a preferred food of marine mammals in the northeast, but squid (both short- and long-finned) are often eaten by mammals in that region.

\section{Implications}

Based on: a) the average body burden of saxitoxin in mackerel over a large geographic region ( $80 \mu \mathrm{g}$ per fish); b) the presence of large quantities of mackerel in whale stomachs; c) the unusual and rapid whale mortality; d) the presence of a saxitoxin-like compound in whale tissues; e) the estimated dose of toxin to the whales from ingestion of mackerel; and f) the probable increase in susceptibility of marine mammals to neurotoxins that affect equilibrium and respiration, it is reasonable to hypothesize that the humpback whale mortality was caused by dinoflagellate toxins accumulated in mackerel. While support for this hypothesis is circumstantial, it is offered as the most likely scenario, in view of the absence of plausible alternatives (Geraci et al., in press).

Other implications of these analyses and results are that:

- mackerel stocks probably contain saxitoxin over a wide range in the northwest Atlantic;

- mackerel probably retain toxin for extended periods of time, possibly converting an initial mixture of the saxitoxins into the parent compound saxitoxin through time;

- since the whale mortality occurred during a year with relatively low shellfish toxicity in the region, unrecognized offshore blooms of Alexandrium may be sources of toxin to fish and whales;

- the long history of PSP in the region combined with the absence of conspicuous whale mortalities in the past suggests that a series of relatively rare events must co-occur to cause a mortality of this type (e.g. decline of sand lance populations, increased mackerel abundance, co-occurrence of dinoflagellates, zooplankton, and planktivorous fish). Frequent repetitions of whale mortality events at this scale are unlikely;

- The presence of toxins in living fish may represent a limited seafood safety risk (discussed below). 


\section{B. Dolphins}

\section{Epidemiology and Pathology}

During the spring and early summer, the inshore migratory stock of bottlenose dolphins (Tursiops truncatus) apparently migrates from its wintering area east of Florida and Georgia northward to the coastal areas between New Jersey and North Carolina. The dolphins return south in the fall. In June 1987, unusual numbers of dolphins began dying and washing-up on beaches in New Jersey. Between June 1987 and February 1988, over 740 dolphins were found dead along their southern migratory route as far south as Florida (Scott et al., 1988). These deaths represent an unknown fraction of total mortality because many other carcasses likely drifted out to sea or were scavanged. Most of the dead dolphins exhibited a wide range of chronic pathological processes typical of those associated with chronic physiological stress. These pathological findings and the distribution of dolphin deaths were not consistent with a primary infectious epizootic disease and no known specific primary infectious pathogen was consistently isolated from dolphin tissues submitted to various laboratories (Geraci, 1989).

Levels of some organic contaminants (PCBs, DDT, trans-nonachlor) in some dolphin tissues were among the highest recorded in cetaceans, but in many animals that died, the levels were in the range found in reference control tissue from aquaruim dolphins that died unrelated to this episode (Geraci, 1989).

Livers yielded extractable substances that were fatal to fish in bioassays (Appendix 3c). These compounds had chemical properties similar to brevetoxins of dinoflagellate origin. In one such dolphin that died off the coast of Florida, the stomach contained menhaden with similar toxic activity in its viscera.

\section{Toxin Assays}

As described in more detail in Appendix 3c, three types of samples were examined to test the hypothesis that Florida red tide brevetoxins can transvect to dolphins: (i) dolphin livers (which must contain demonstrable brevetoxins); (ii) stomach contents from moribund dolphins (which must contain prey adulterated with brevetoxins); and (iii) live-caught prey species (which must 
contain brevetoxins). Thirty-four samples of (i) were examined, one suitable sample of (ii) was analyzed, and limited numbers of eight species of type (iii) were tested.

Samples were prepared by extraction/homogenization in solvent, followed by sequential flash chromatography, multiple thin-layer chromatography, and reverse phase high performance liquid chromatography. For a single subsample of (i), Fourier transform infrared spectrometry and brevetoxin radioimmunoassy were performed. Procedurally, following each chromatographic step, Gambusia affinis fish bioassays were performed to assess each subfraction for potential toxicity. Work-ups were terminated if bioassays ceased to be positive. Only positive fractions were carried to the subsequent step in the purification scheme. HPLC fractions were compared to reference standard brevetoxins, on the basis of retention times and co-migration (i.e. mixing of resolved peaks from the suspect fractions with authentic brevetoxin and re-chromatography). Fractions not reaching the HPLC stage were classified as non-brevetoxin, as were samples which did not demonstrate brevetoxin-type HPLC peaks.

By the criteria listed above, eight of the 17 samples of (i) tested positive for brevetoxins compared to negative results for 17 submitted control samples of (i). The single sample of (ii) tested positive, and samples of menhaden viscera but not other species from (iii) also tested positive.

Sample WAM-280, which tested positive by all criteria, was subjected to Fourier transform infrared spectrometry and was compared to standard brevetoxin. Spectra of the two compounds were indeed very similar but were not identical. This was the only spectrum analysis which could be obtained due to sample limitations. Brevetoxin radioimmunoassay was also performed on this sample, using tritiated brevetoxin $\mathrm{PbTx}-3$ as a ligand probe and brevetoxin-specific goat polyclonal antibody as the binding component. A calculated $\mathrm{IC}_{50}$ (concentration necessary to displace $1 / 2$ the labeled toxin from the antibody) for WAM-280 HPLC-resolved "brevetoxin" is $7.3 \mathrm{~nm}(\sim 900$ $\mathrm{MW}$ ), compared with an $\mathrm{IC}_{50}$ for $\mathrm{PbTx}-3$ of $2.5 \mathrm{~nm}$. Thus, the resolved WAM-280 sample appears to be recognized by antibrevetoxin antibodies. 


\section{Potential Interactions}

Toxic, lipid-soluble extracts from menhaden viscera and dolphin liver had physical and chemical properties equivalent to brevetoxins using the above methods. If biotoxins are being transferred via food chains, what then are the potential implications of such events to seafood product safety and health of higher carnivores or omnivores? Because bottlenose dolphins from the $1987-88$ mortalities contained brevetoxin-like substances ( 83 to $15,820 \mathrm{ng} / \mathrm{g}$ liver tissue) (Geraci, 1989), it is probable that they came in contact with the toxic organisms directly in the water column, or indirectly through the food chain. Direct contact is unlikely to cause accumulation of toxins in liver tissue and has apparently not caused mass mortalities of dolphins off the west coast of Florida, where $P$. brevis red tides can be intensive (concentration of $>180,000$ cells ml$^{-1}$ ) and of long duration. Toxicity through the food chain is much more plausible because dolphins consume fish whole, and if prey items have toxic viscera, dolphins could be killed or possibly be compromised to the point of nonfeeding, modification of behavior and orientation, and/or immunoincompetency. Several synergistic factors other than biotoxins could have been involved in the 1987-88 mortalities, and caused physiological stress and debilitation.

Hersh (1987) characterized the seasonal occurrences of bottlenose dolphins as the following: 1) North Carolina to New Jersey in summer, 2) Carolinas to Florida in fall, with a concentration in northeast and central Florida coastal waters in winter, and 3) a northerly migration in spring. Scott et al. (1988) diagramed the 1987-88 east coast dolphin strandings starting with the summer mortalities between New Jersey and North Carolina (see Figures 1 and 2). Dolphin strandings correlate with known seasonal occurrences and timing of migrations. 

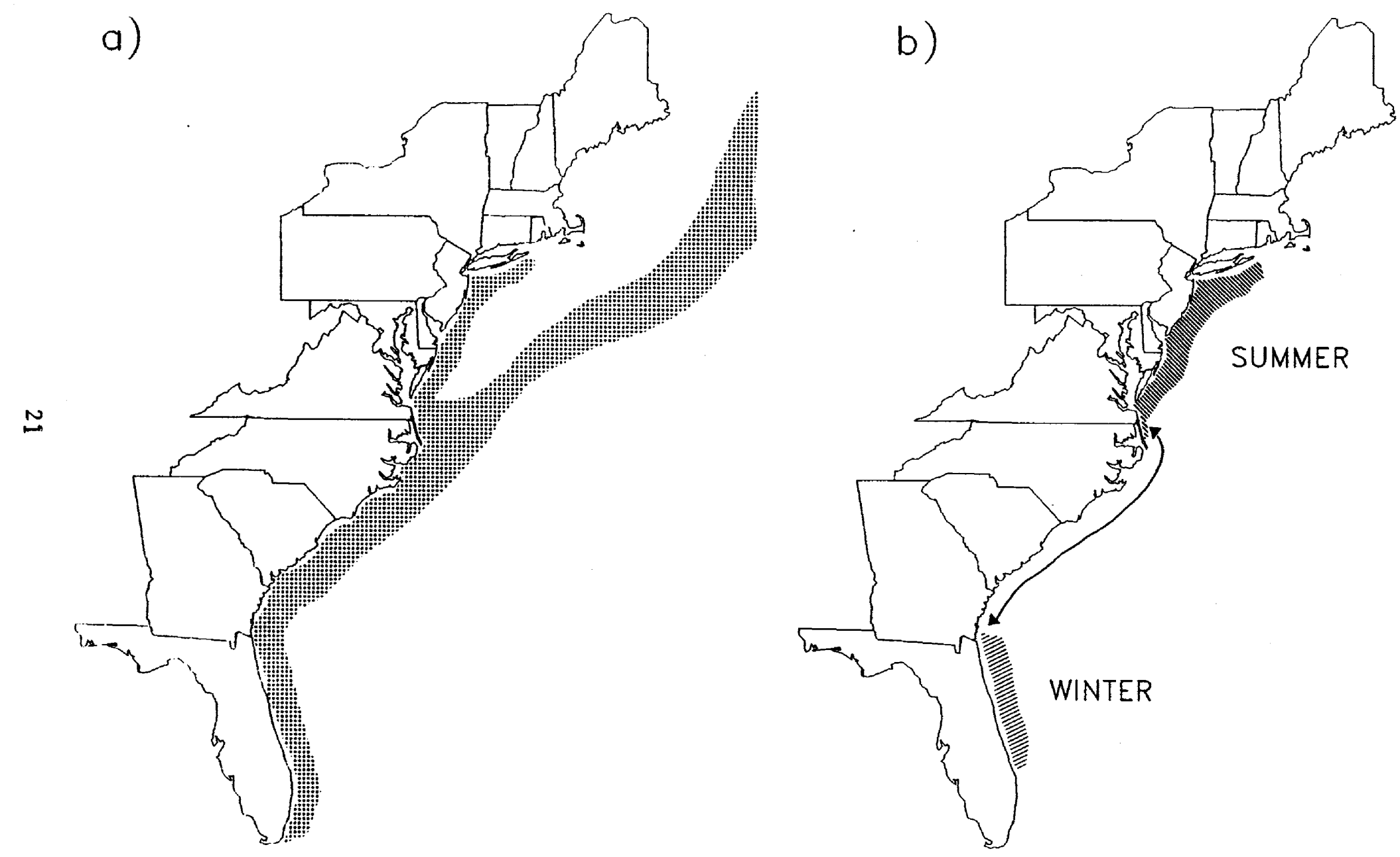

Figure 1 (Scott et al., 1988). a) Distributional range of bottlenose dolphins along the U.S. At lantic coast. b) Areas of major concentrations of coastal migratory stock of bottlenose dolphins during summer and winter. 


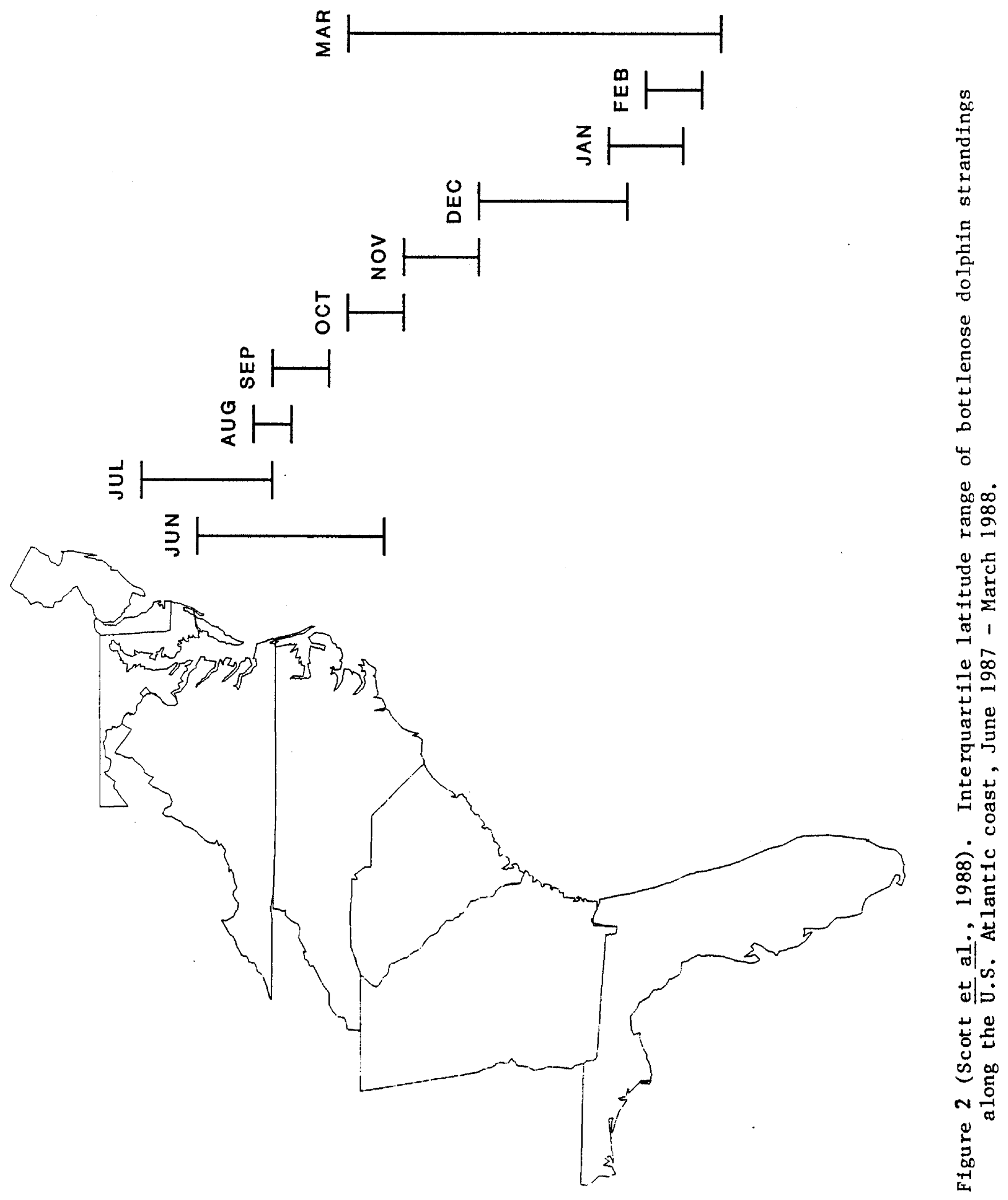


Several of the dolphin prey species have the same distribution and occurrence patterns along the Florida and northeast U.S. coast; this has been revealed by tag-and-recapture studies and data on seasonal fishery landings by area. Dolphins feed on menhaden and other clupeid or herring-like fishes. Atlantic menhaden tagged in northeast Florida nearshore waters in April were recaptured in North Carolina in May/June and menhaden tagged in North Carolina in early spring have been returned from Chesapeake Bay in May and New Jersey and New York in July (Dryfoos et al., 1973). These data may be misleading, however, as tag returns from processing plants are not always indicative of area of harvest. These distribution and migratory patterns are probably associated with water temperature changes and other cues, e.g., availability of food. The toxic menhaden from dolphin stomach contents was not identified to species; the live menhaden caught off Vero Beach, Florida was thought to be $B$. smithi . However, all menhaden are planktivorous and could conceivably be toxin vectors, as could other coastal fishes such as Spanish mackerel and striped mullet, which are also food items of coastal dophins. It is possible that predator and prey travel the same routes at approximately the same times, or that they at least occur in the same area at the same time.

Confounding the apparent relationship between coastal bottlenose dolphins and brevetoxins is the occurrence of other potential toxin-producing planktonic flagellates. Tursiops and toxic flagellates are present in both the Atlantic and the Gulf of Mexico regions of Florida. If east coast dolphins were affected by brevetoxins, as has been proposed (Geraci, 1989), the lack of previous observations of similar catastrophic dolphin mortalities in the Gulf of Mexico would need to be explained. Several possible explanations for this apparent discrepancy are discussed below as hypotheses.

The first documented case of coincidental $P$. brevis red tide and mass marine mammal mortalities in the Gulf of Mexico occurred in 1982 when 41 West Indian manatees died between February and April in Charlotte Harbor (O'Shea and Rathbun, 1982). Although brevetoxins were certainly suspect, they were not confirmed in tissues. Toxic substances were found in filterfeeding tunicates that were collected from the same vegetated area where manatees were feeding. 
Tunicates were also found in the gastrointestinal tract of dead manatees. Eight distressed manatees exhibited neurological signs of dysfunction, e.g., disorientation, inability to submerge, flexing of the back, listlessness, and labored breathing; one of these manatees died and several were revived. Such signs are suggestive of brevetoxin intoxication.

\section{Implications}

It is clear that a brevetoxin-like compound was present in livers of some dolphins that died during the epizootic in 1987 and in ingested and wild menhaden. The seafood safety concerns of these data are discussed below. The detection of these toxins, combined with knowledge of the geographic occurrence of dinoflagellate blooms off southern Florida and the migration patterns of dolphins and their food fish, suggests one scenario in which the dinoflagellate toxins initiated the mortality event (Geraci, 1989). This possibility, which led to much discussion, was the only one offered that was consistent with the range of available data regarding the die-off. Futhermore, it is supported by the same lines of evidence used to implicate STX in the whale mortalities. The major difficulties in assessing this possibility include:

- the lack of documented direct temporal and spatial coupling between blooms of the dinoflagellate $P$. brevis and the initial dolphin deaths along the mid-Atlantic coast;

- most dolphin deaths apparently were caused by a variety of different pathogens, requiring that the effect of brevetoxin would have to be limited to a non-lethal physiological insult;

- dolphins in the Gulf of Mexico inhabit an environment subject to frequent brevetoxincontaining red tides. If the above hypothesis is true, these dolphins must be either resistant to brevetoxins in their usual food-fish, or they avoid specific fish species or regions at times when the risk is high. 


\section{SEAFOOD SAFETY}

\section{A. Summary of Dinoflagellate Toxins in Fish}

After the first discovery of toxin in mackerel liver and the confirmation of saxitoxin, the question of public health became an important issue. Personnel from the Massachusetts Department of Public Health, Maine Department of Marine Resources, and the National Marine Fisheries Service, Northeast Fisheries Center (NEFC) immediately began sampling other species of fish and edible tissues to determine if the toxin problem in mackerel livers was indicative of a more general seafood safety problem. In December 1987, the Massachusetts Department of Public Health issued a health Advisory recommending that consumers not purchase mackerel. After futher study, it was determined that toxins were only found in livers and not in muscle tissue. The Advisory was accordingly updated to state that there was no risk of saxitoxin exposure from consumption of mackerel flesh.

From December 1987 to May 1989 the NEFC Gloucester Laboratory continually sampled Atlantic mackerel over the entire geographic range of the species from the mid-Atlantic to the Gulf of St. Lawrence. During this period, over 100 discrete samples of mackerel (individual as well as composite samples) have been analyzed by the AOAC mouse bioassay test (Adams and Meiscier, 1980).

Mackerel livers demonstrated toxicity with toxin levels ranging from less than $40 \mu \mathrm{g}$ to as much as $600 \mu \mathrm{g} / 100 \mathrm{~g}$ of liver. No toxin was found in edible muscle tissues or in other Atlantic mackerel products including canned mackerel pet food and mackerel roe. Additionally, liver and some flesh samples from 23 other species of fish and shellfish were screened for the presence of toxins. These included sea urchins, northern shrimp, groundfish species such as cod, haddock and pollock, skates and dogfish, flounder species, hakes and related scombroid species such as bluefin tuna and king, frigate and Pacific mackerels (Learson, pers. comm.). To date, no evidence of toxins in either livers or edible portions has been found in any of these species. Independently, personnel from the states of Maine and Massachusetts examined edible tissues or products from 
similar species and other products such as canned Maine sardines and dolphin (fish) with the same negative bioassay results.

Other studies in Canada, the Pacific Ocean and, most recently, the south Atlantic have demonstrated the presence of dinoflagellate toxins in mackerel, herring (dead), sand lance (dead), a variety of planktivorous fishes from Southeast Asia, and menhaden. Again, there is no evidence that toxins are present in any muscle tissues or edible roe.

Although there is no evidence of PSP-type toxins or brevetoxins in edible muscle tissues from finfish, sampling should be continued on filter-feeding species and their predators during and after phytoplankton blooms. Analysis should include screening for PSP toxins as well as for domoic acid which has recently been implicated in human illnesses related to shellfish consumption.

The only other potential food safety problem associated with bioaccumulation of PSP toxins or brevetoxins in filter-feeding species would be in the production of fish meal and oil. Insufficient information is available at present to ascertain whether a danger exists with these products, but the dilution of toxic tissues by the more abundant non-toxic portions during processing or the use of caustic soda during processing (for menhaden oil) should minimize problems.

\section{B. Human and Animal Concerns}

\section{Whole Fish Uses}

All available evidence points to fish viscera being the only potentially hazardous material. The consumption of whole fish, including viscera, may therefore present an increased risk to individuals, usually members of certain ethnic groups, who include such items in their diet. The consumption patterns of these special population groups are not known. Future seafood consumption surveys should be designed to provide information on species of fish used as well as the size and frequency of meals. 
Atlantic mackerel and squid, both of which have exhibited toxic viscera, are among the species to be considered. Squid viscera are often discarded, but the ink, the toxin content of which is not known, is frequently used in food preparations.

In the case of animal feeds, potential sources of contamination are toxic, whole fish supplied to zoos or processed into pet foods. Heat processing is known to significantly reduce levels of certain toxins such as PSP toxin in the finished product (Prakash et al., 1971).

\section{Other Fish Products}

Available information on toxicity levels, as well as historical data on product safety, suggests that consumption of fish viscera, or products derived from or including fish viscera, under most circumstances would not be toxic to the ultimate consumer. Products which fall in this category range from major commodities such as fish meal and oil to speciality food items such as "Gentlemen's Relish", a condiment prepared from mackerel viscera.

Fish Meal and Oil: The major source of raw material for this industry is menhaden (both Gulf and Atlantic species). Menhaden, like many other fish species are apparently sensitive to red tide toxins and do not survive intoxications. It is assumed, reasonably, that healthy fish caught and processed are free of toxin. Also, if brevetoxin were present in the viscera of the menhaden at levels sub-lethal to the fish, it would be effectively destroyed in the subsequent heat processing operations leading to the meal and oil products. Similar considerations would apply in the case of meal and oil products derived from Atlantic herring and mackerel.

\section{RESEARCH AND MONITORING PRIORITIES}

It is convenient to discuss the research needed to address the marine mammal mortalities in the context of hypotheses and the data needed to test them. It should be noted that the workshop participants agree that these are valid hypotheses, but disagree on the liklihood of their being correct. 


\section{A. Whale Mortalities}

Hypothesis 1. Whale mortalities in 1987 were caused by consumption of mackerel containing the natural biotoxin saxitoxin.

Rationale: This hypothesis is not rigorously testable. Should such a mortality event occur again, information on the following would be necessary for addressing the related hypotheses described below:

Information Needs:

- toxicity information on mackerel, sand lance and other prey items of humpback whales throughout the region and over time, including but not limited to times and places where unusual mortalities occur.

- appropriate analyses of whale tissues and stomach contents should be performed as quickly as possible after mortality events (See Appendix 2).

- toxin pharmacokinetics (see below)

Hypothesis 2. Mackerel process the saxitoxins differently from other fishes.

Rationale: The effects of chronic exposure of fish to low levels of toxins are unknown. Mackerel are of special interest because they can carry substantial levels of toxins in internal organs in a range similar to body burdens known to kill other fishes. A logical approach would relate to the food web, beginning with plankton feeders (menhaden, herring, sand lance, etc.) and progressing to carnivores.

Information Needs:

- pharmacokinetics of the saxitoxins in various fishes. (Rates of toxin uptake, accumulation and release; tissue distributions and bioconversions).

- responses to chronic, sub-lethal doses

Hypothesis 3. The source of toxins in mackerel is the dinoflagellate Alexandrium (formerly Protogonyaulax ). 
Rationale: In this region, all PSP episodes are typically linked to Alexandrium species, although there is a suggestion in the recent literature that bacteria might be capable of producing the saxitoxins.

Information Needs:

- dinoflagellate and zooplankton population dynamics, distribution, and toxicity (emphasizing offshore occurrences)

- evidence of bacteria that might produce the saxitoxins in fish.

Hypothesis 4. The saxitoxins are converted in whale tissues.

Rationale: Extracts from whale tissues were toxic upon bioassay but showed none of the saxitoxins under HPLC analysis. Decarbamoylation or other conversions are suspected. Information Needs:

- model animal studies of chronic, low-level exposure to saxitoxin.

- whale tissue analyses (from suspected biotoxin mortality events) for decarbamoyl toxins using HPLC and single sodium channel analysis.

- use harbor porpoises taken incidentally in Bay of Fundy and Maine fisheries along with the Joint Venture Mackerel Fishery in the mid-Atlantic as a source of samples to determine toxin distribution in marine mammal tissues and the modes of toxin acquisition.

\section{B. Dolphin Mortalities}

It has been hypothesized that dophins were poisoned by brevetoxin, a neurotoxin produced by the Florida red tide dinoflagellate Ptychodiscus brevis, and were subsequently affected by a host of bacterial and viral pathogens (Geraci, 1989). The design of strategies to test this hypothesis is restricted by the inability to examine these phenomena in controlled experiments using marine mammals. Futhermore, at this time the weight of the evidence is too weak to justify direct feeding studies on dolphins. A strategy can be developed to test the hypothesis indirectly by the following steps.

Hypothesis 1. Brevetoxins can be acquired in filter-feeding fish and other prey items. 
Rationale: Toxic compounds were unequivocally detected in menhaden, although the final chemical identification as brevetoxin is not complete.

Information Needs:

- pharmacokinetics of brevetoxin exposure to various fishes.

Hypothesis 2. Tursiops in west-central Florida are not exposed to or do not ingest food containing brevetoxins.

Rationale: Despite a long history of toxic red tide and Tursiops co-occurrences in the Tampa region, there are no records of high dolphin mortalities there.

Information Needs:

- collect and analyze dolphin prey items for toxins in and near areas inhabited by dolphins

- lavage animals and test stomach contents

- collect and test tissue samples and stomach contents from beached dolphin carcasses

Hypothesis 3. Florida east coast dolphins can ingest food containing brevetoxins.

Rationale: East coast dolphins were those involved in the mortality event. Liver analyses of many dead animals were positive for brevetoxin-like compounds.

Information Needs:

- seasonal analyses for brevetoxins in fish from locations when the unusual dolphin mortality occurred

- tissue analyses (for brevetoxin) of animals taken as part of the incidental catch in east coast fisheries and found stranded along east coast beaches.

Hypothesis 4. Chronic exposure to sub-lethal doses of brevetoxins is physiologically damaging to dolphins.

Rationale: This hypothesis is testable directly only through live animal experiments. Tests on live dolphins probably cannot be justified at this time. Exposure testing on other model mammals may provide insight into its validity. For example, there is evidence from animals used 
to produce antibodies that sub-lethal inoculations with brevetoxin can result in eventual death from secondary causes, not from the toxin directly.

Information Needs:

- Physiological studies of sub-lethal brevetoxin effects using animal models (not marine mammals).

Hypothesis 5. The source of the toxins in menhaden and dolphins is Ptychodiscus brevis or other gymnodinioids.

Rationale: A variety of assays and analyses demonstrates the presence of brevetoxin-like compounds in fish and dolphin tissues.

Information Needs:

- NMR, spectroscopic analysis of toxin extracts from experimental and wild fish and mammals

\section{Seafood Safety}

Since the fish shown to contain saxitoxin or the brevetoxin-like compounds are part of the east coast commercial fishery, concern has been raised as to the implications for seafood safety. Hypothesis 1. Dinoflagellate toxins linked to marine mammal deaths do not contaminate fish flesh.

Rationale: All evidence from field and laboratory studies indicates that fish are sensitive to dinoflagellate toxins and die before they accumulate detectable amounts in their flesh. Information Needs

- monitoring (by bioassay) of flesh from fish of chief concern during blooms. This would be conducted most expeditiously within the context of the newly-established national seafood monitoring program (NOAA/FDA).

- feeding studies on fish

Hypothesis 2. The consumption of viscera contaminated with dinoflagellate toxins or of products using those viscera may present a human health risk. 
Rationale: Certain ethnic groups do consume whole fish, including the internal organs. Human mortalities from PSP through this route have been documented in Southeast Asia. Information Needs:

- monitor toxin levels in viscera of fish (national seafood monitoring program)

- develop specific, reproducible, rapid, quantitative methods for detecting dinoflagellate toxins (especially brevetoxins) in seafood

- feeding studies with fish

- toxin stability studies in different product forms (meal, oil)

\section{RECOMMENDATIONS}

In the preceding sections, a series of hypotheses have been listed, along with strategies for testing them. The workshop participants recommended that the proposed studies be given high priority in future research. All of the issues are important, with no items having higher priority than others.

In addition, the participants recommended the following:

- The protocol for the examination of beached animals given in Appendix 2 be adopted by stranding networks.

- Funds be allocated for the chemical analyses and assays needed to ascertain the presence or absence of dinoflagellate toxins in the tissues of beached marine mammals.

- Given that the weight of the current evidence linking the brevetoxins to dolphin mortalities is circumstantial, direct feeding studies on dolphins are not justifiable.

- Present shortages of certain toxin standards be alleviated by the preparation and distribution of approved materials. 


\section{ACKNOWLEDGEMENT}

We gratefully acknowledge the following organizations for providing the support needed to convene this workshop and prepare these proceedings: National Marine Fisheries Service, the Coastal Research Center of the Woods Hole Oceanographic Institution (under a grant from the Andrew W. Mellon Foundation); NOAA National Sea Grant College Program Office, Department of Commerce; under Grant No. NA86-AA-D-090, WHOI Sea Grant Project Nos. R/B-92 and M/0-2; and the U.S. Marine Mammal Commission. We also wish to thank B. W. Tripp for helping to organize and run the workshop and to edit the report. Olimpia McCall deserves our thanks for typing a coherent report from a collection of handwritten pieces. 


\section{REFERENCES}

Adams, J.A., D.D. Seaton, J.B. Buchanan and M.R. Longbottom. 1968. Biological observations associated with the toxic phytoplankton bloom off the east coast. Nature 220: $24-25$.

Adams, W. N. and J. J. Meiscier. 1980. J. Official Analytical Chem. 63: 1336-1343.

Adnan, Q. 1984. Distribution of dinoflagellates at Jakarta Bay; Taman Jaya, Banten; and Benoa Bay, Bali; and a report of an incidence of fish poisoning at Eastern Nusa Tenggara. p. 2527, In: Toxic Red Tides and Shellfish Toxicity, A.W. White, M. Anraku and K.K. Hooi (eds.), Southeast Asian Fisheries Development Center, Singapore.

Baden, D. G. 1983. Marine food-borne toxins. Int. Rev. Cytol. 82: 99-150.

Berrien, P. and D. Finan. 1977. Biological and fisheries data on King mackerel, Scomberomorus cavalla (Cuvier). Nat. Mar. Fish. Ser., Sandy Hook Laboratory, Highlands, New Jersey, Tech. Ser. Rep. No. 8.42 pp.

Cembella, A. D., J. Turgeon, J. C. Terriault and P. BeLand. 1988. Spatial distribution of Protogonyaulax tamarensis resting cysts in nearshore sediments along the north coast of the lower St. Lawrence estuary. J. Shellfish Res.: 7: 587-596.

Dryfoos, R. L., R. P. Cheek, and R. L. Kroger. 1973. Preliminary analyses of Atlantic menhaden, Brevoortia tryannus, migration, population structure, survival and exploitation rates, and availability as indicated from tag returns. Fishery Bulletin 71: 719-734.

Evans, M.H. 1972. Tetrodotoxin, saxitoxin, and related substances: their applications in neurobiology. Int. Rev. Neurobiol. 15: 83-166.

Forrester, D. J., J. M. Gaskin, F. H. White, N. P. Thompson, J. A. Quick, Jr., G. E. Henderson, J. C. Woodard and W. D. Robertson. 1977. An epizootic of waterfowl associated with a red tide episode in Florida. Journal of Wildlife Diseases 13: 160-167.

Geraci, J. R. 1989. Clinical investigation of the 1987-88 mass mortality of bottlenose dolphins along the U.S. central and south Atlantic coast. Final report to National Marine Fisheries Service and U.S. Navy, Office of Naval Research and Marine Mammal Commission, April 1989.

Geraci, J.R., D.M. Anderson, R.J. Timperi, D.J. St. Aubin, G.A. Early, J.H. Prescott and C.A. Mayo. Humpback whales fatally poisoned by dinoflagellate toxins. Can. J. Fish. Aquat. Sci. (in press).

Gilmartin, W. G. 1987. Hawaiian monk seal die-off response plan, A workshop report, 2 April 1980, San Diego, CA. NMFS Administrative Report H-87-19.

Gunter, G., R. H. Williams, C. C. Davis and F. G. Smith. 1948. Catastrophic mass mortalities of marine animals and coincidental phytoplankton bloom on the west coast of Florida, November 1946 - August 1947. Ecol. Monog. 18: 309-324. 
Hall, S. and P. B. Reichardt. 1984. Cryptic paralytic shellfish toxins. In: Seafood Toxins, E. P. Ragelis, (Ed.). Amer. Chem. Soc., Wash. DC. pp. 113-123.

Haya, K., J.L. Martin, B.A. Waiwood, L.E. Burridge, J. Hungerford and V. Zitko. 1989. Identification of paralytic shellfish toxins in mackerel from Southwest Bay of Fundy, Canada. In: 4th Int. Conf. on Toxic Marine Phytoplankton, Lund, Sweden. (in press).

Hayashi, T., Y. Shimizu and A.W. White. 1982. Toxin profile of herbivorous zooplankton during a Gonyaulax bloom in the Bay of Fundy. Bull. Jap. Soc. Sci. Fish. $48: 1673$.

Hersh, S. L. 1987. Characterization and differentiation of bottlenose dolphins populations (genus Tursiops ) in the southeastern U.S. based on mortality patterns and morphometrics. Univ. of Miami, Coral Gables, Fl. Ph. D. dissertation. 213 pp.

Jonas-Davies, J. and J. Liston. 1985. The occurrence of PSP toxins in intertidal organisms. p. 467-472, In: Toxic Dinoflagellates, D.M. Anderson, A.W. White and D.G. Baden (eds.), Elsevier, NY.

Kogure, K., M. L. Tamplin, U. Finidu and R. R. Colwell. 1988. A tissue culture assay for tetrodotoxin, saxitoxin and related toxins. Toxicon 26: 191-197.

Lackey, J. B. 1969. Microbiological studies in the FWPCA project area with comparisons to other subtropical and tropical areas, p. 52-85. In R. F. McAllister (ed.), Demonstration of the limitations and effects of waste disposal of an ocean shelf. Fla. Ocean Sci. Inst. Rep. AR-69-2.

Laws, R. M. and R. J. F. Taylor. 1957. A mass dying of crab-eater seals, Lobodon carcinophagus (Grey). Proc. Zoo. Soc. London. 129: 315-324.

Maclean, J. L. 1989. Indo-Pacific red tides, 1985-1988. Marine Pollution Bulletin 20: 304-310.

Maranda, L., D. M. Anderson and Y. Shimizu. 1985. Comparison of toxicity between populations of Gonyaulax tamarensis of eastem North American Waters. Est. Coast. Shelf Sci. 21: 401-410.

Marshall, H. G. 1980. Phytoplankton distribution along the eastern coast of the U.S.A. Part III. Checklist of phytoplankton. Sp. Report 101. Old Dominion Univ. Res. Foundation, Norfolk, VA. 19 pp.

Marshall, H. G. 1982. The composition of phytoplankton within the Chesapeake plume and adjacent waters of the Virginia coast, U.S.A. Est., Coast. and Shelf Sci. 15: 29-43.

Martin, J. L. and A. W. White. 1988. Distribution and abundance of the toxic dinoflagelate Gonyaulax excavata in the Bay of Fundy. Can. J. Fish. and Aquat. Sci. 45: 1968- 1975.

Nakamura, M., Y. Oshima and T. Yasumoto. 1984. Occurrence of saxitoxin in pufferfish. Toxicon 22: 381-385.

Nisbet, I.C.T. 1983. Paralytic shellfish poisoning: Effects on breeding terns. Condor 85: 338345 .

O'Shea, T. J. and G. B. Rathbun. 1982. Summary report on a die-off of the West Indian manatee (Trichechus manatus ) in Lee County, Florida, Spring 1982. 3 volumes. Sirenia Project Report, Gainesville, Florida. 
Oshima, J. , T. Yasumoto, M. Kodama, T. Ogata, Y. Fukuyo, and F. Matsuura. 1982. Features of paralytic shellfish poison occurring in Tohoku District. Bull. Jpn. Soc. Sci. Fish. 48: 525-530.

Pierce, R., Mote Marine Laboratory, Sarasota, FL, Personal Communication.

Pierce, R. H. 1986. Red tide (Ptychodiscus brevis) toxin aerosols: a review. Toxicon 24: $955-$ 966.

Prakash, A., J. C. Medcof and A. D. Tenant. 1971. Paralytic Shellfish Poisoning in Eastern Canada. Fisheries Research Board of Canada, Bulletin 177.

Proctor, N. H., S. L. Chan and A. J. Trevor. 1975. Production of saxitoxin by cultures of Gonyaulax catenella. Toxicon 13: 1-19.

Roberts, B. S. (FMRI, unpublished data).

Roberts, B. S. 1979. Occurrence of Gymnodinium breve red tides along the west and east coasts of Florida during 1976 and 1977, p. 199-202. In D. L. Taylor and H. H. Seliger (eds.), Toxic Dinoflagellate Blooms, Elsevier/North Holland, Inc., N.Y.

Saloman, C. H. and S. P. Naughton. 1983. Food of Spanish mackerel, Scomberomorus maculatus, from the Gulf of Mexico and southeastern seaboard of the United States. NOAA Tech. Mem. NMFS-SEFC-128. 22 pp.

Schantz, E.J., V.E. Ghazzarossian, H.K. Schnoes, F.M. Strong, J.P. Springer, J.O. Pezzanite and J. Clardy. 1975. Paralytic poisons from marine dinoflagellates. p. 267-274, In: First Int. Conf. on Toxic Dinoflagellate Blooms, V.R. LoCicero (ed.), Mass. Sci. Tech. Found., Wakefield.

Scott, G. P.; D. M. Burn and L. J. Hansen. 1988. The dolphin die-off: long-term effects and recovery of the population. Proc. Oceans '88, Baltimore, MD. pp. 819-823.

Sergeant, D.E. 1969. Feeding rates of Cetacea. FiskDir. Skr. Ser. HavUnders. 15: 246-258.

Sette, O. E. 1950. Biology of the Atlantic mackerel (Scomber scombrus) of North America. Copenhagen, Denmark: Part 2: Migrations and Habits. U.S. Fish Bulletin 51 (49): 251358.

Shimizu, Y. and M. Yoshioka. 1981. Transformation of paralytic shellfish toxins as demonstrated in scallop homogenates. Science 212: 547-549.

Shimizu, Y. 1987. Dinoflagellate Toxins. In: The Biology of the Dinoflagellates, F. J. R. Taylor, (Ed.). Blackwell Scientific, Oxford. pp. 282-315.

Steidinger, K. A., M. A. Burklew and R. M. Ingle. 1973. The effects of Gymnodinium breve toxin on estuarine animals, p. 179-202. In D. Martin and G. Padilla (eds.), Marine Pharmacognosy, Academic Press, N. Y.

Steidinger, K. A. and K. D. Haddad. 1981. Biologic and hydrographic aspects of red tides. Bioscience 31 (11): 814-819. 
Steidinger, K. A. and D. G. Baden. 1984. Toxic marine dinoflagellates, p. 201-249. In D. L. Spector (ed.) Dinoflagellates, Academic Press, Orlando.

Sullivan, J. J., W. T. Iwaoka and J. Liston. 1983. Enzymatic transformation of PSP toxins in the little neck clam (Protothaca staminea ). Biochem. Biophys. Res. Comm. 114: 465472.

Sullivan, J. J., M. M. Wekell and L. L. Kentala. 1985. Application of HPLC for the determination of PSP toxin in shellfish. J. Food Sci. 50: 26-29.

Tester, P. A., P. K. Fowler and J. T. Turner. Gulf Stream transport of the toxic red tide dinoflagellate, Ptychodiscus brevis from Florida to North Carolina. In Proceedings of Symposium on Novel Phytoplankton Blooms: Causes and Impacts of Recurrent Brown Tides and Other Unusual Blooms, October 27-28, 1988, Stony Brook, N.Y. (in press).

Therriault, J. C., J. Painchand and M. Levasseur. 1985. Factors controlling the occurrence of Protogonyaulax tamarensis and shellfish toxicity in the St. Lawrence Estuary: Freshwater runoff and the stability of the water column. pp. 141-146. In: Toxic Dinoflagellates, (Anderson, D. M., A. W. White and D. G. Baden, Eds.), Elsevier, N.Y.

White, A.W. 1979. Dinoflagellate toxins in phytoplankton and zooplankton fractions during a bloom of Gonyaulax excavata . p. 381-384, In: Toxic Dinoflagellate Blooms, D.L. Taylor and H.H. Seliger (eds.), Elsevier, NY.

White, A.W. 1980. Recurrence of kills of Atlantic herring caused by dinoflagellate toxins transferred through herbivorous zooplankton. Can. J. Fish. Aquat. Sci. 37: 2262-2265.

White, A.W. 1981a. Marine zooplankton can accumulate and retain dinoflagellate toxins and cause fish kills. Limnol. Oceanogr. 26: 104-110.

White, A.W. 1981b. Sensitivity of marine fishes to toxins from the red-tide dinoflagellate Gonyaulax excavata and implications for fish kills. Mar. Biol. 65: 255-260.

White. A.W. 1984. Paralytic shellfish toxins and finfish. p. 171-180, In: Seafood Toxins, E.P. Ragelis (ed.), ACS Symposium Series 262, Amer. Chem. Soc., Washington, D.C.

White, A.W., O. Fukuhara and M. Anraku. 1989. Mortality of fish larvae from eating toxic dinoflagellates or zooplankton containing dinoflagellate toxins. p. 395-398, In: Red Tides: Biology, Environmental Science and Toxicology, T. Okaichi, D.M. Anderson and T. Nemoto (eds.), Elsevier, NY.

Williams, J., W. F. Grey, E. B. Murphy and J. J. Crane. 1977. Drift bottle analysis of eastern Gulf of Mexico surface circulation. Mem. Hourglass Cruises. Vol. 4. 134 pp.

Wyatt, T. 1980. Morrell's seals. J. Cons. int. Explor. Mer 39: 1-6. 


\section{APPENDIX 1}

\section{Participants}

Woods Hole Oceanographic Institution Conveners:

Dr. Donald Anderson

Department of Biology

Clark 405B

Woods Hole, MA 02543

Dr. Alan White

(508) 548-1400 ext: 2351

Sea Grant Program

Woods Hole, MA 02543

(508) 548-1400 ext: 2289

Mr. Bruce Tripp

Coastal Research Center

Woods Hole, MA 02543

(508) 548-1400 ext: 2900

*Not present at workshop: assisted with proceedings, review and revision

Dr. Daniel G. Baden

Department of Biochemistry (R629)

University of Miami School of Medicine

P.O. Box 016129

Miami, FL 33101

(305) $547-6516$

Dr. Eugene Fritz

National Sea Grant College Program

$\mathrm{R} / \mathrm{SE} 1$

6010 Executive Boulevard

Rockville, MD 20852

(301) 443-5940

Dr. Joseph R. Geraci

Department of Pathology

Ontario Veterinary College

University of Guelph

Guelph, Ontario N1G 2W1

Canada

(519) $823-8800 \times 4635$

Dr. Sherwood Hall

Food and Drug Administration

$\mathrm{HFF}-454$

200 C Street, SW

Washington, DC 20204

(202) 245-8418
Dr. M.A. Hayes

Department of Pathology

Ontario Veterinary College

University of Guelph

Guelph, Ontario N1G 2W1

Canada

(519) 823-8800

*Dr. Robert Hofman

U.S. Marine Mammal Commission

1625 Eye Street, NW

Washington, DC 20006

(202) 653-6237

Mr. John W. Hurst

Department of Marine Resources

West Boothbay Harbor, ME 04575

(207) 633-5572

Mr. Robert J. Learson

Gloucester Laboratory

NEFC, NMFS

Emerson Avenue

Gloucester, MA 01930

(508) $281-9300 \times 313$ 
Dr. Malcomb Meaburn

Charleston Laboratory, JEFC, NMFS

P.O. Box 12607

217 Fort Johnson Road

James Island

Charleston, SC 29412

(803) 762-1200

Dr. William J. Overholtz

NOAA/NMFS/NEFC

Woods Hole, MA 02543

(508) 548-5123

Dr. Yuzuru Shimizu

Department of Pharmacognosy

\& Environmental Health Sciences

University of Rhode Island

Kingston, RI 02881

(401) 792-2751

Dr. Tim Smith

NOAA/NMFS/NEFC

Woods Hole, MA 02543

(508) 548-5123

Dr. David J. St. Aubin

Department of Pathology

University of Guelph

Guelph, Ontario N1G ZW1

Canada

(519) $823-8800$

Dr. Karen A. Steidinger

Bureau of Marine Research

Florida Department of Marine Resources

100 Eighth Avenue, SE

St. Petersburg, FL 33701

(813) $896-8626$

*Dr. Michael Tillman

NOAA/NMFS, Fx1

1335 East West Highway

Silver Springs, MD 20910

(301) 427-2239

Mr. Ralph Timperi

Massachusetts Department of Public

Health Laboratory

305 South Street

Jamaica Plain, MA 02130

(617) $522-3700 \times 101$
${ }^{*}$ Mr. John Twiss

U.S. Marine Mammal Commission

1625 Eye Street, NW

Washington, DC 20006

(202) 653-6237

Dr. Peter Tyack

Department of Biology

Woods Hole Oceanographic Institution

Woods Hole, MA 02543

(508) 548-1400 x 2818 


\section{APPENDIX 2}

\section{Beached Animal Protocol}

Tissue samples must be collected as soon as possible from beached marine mammals to establish the extent and frequency of their exposure to algal toxins. For the most part, these samples can be collected as part of existing stranding recovery networks in place along most of the U.S. coast. The networks should be instructed to:

- Collect and freeze (on dry ice if possible) $1 \mathrm{~kg}$ samples of liver, and representative samples of stomach contents (first compartment in cetaceans) from any marine mammal examined within 2-3 days after death. Stomach fluid (up to $1 \mathrm{~L}$ ) should also be collected.

- Collect and freeze (on dry ice if possible) $500 \mathrm{~g}$ samples of blubber, kidney and milk from any freshly dead marine mammal.

- If a carcass is old, only liver and stomach contents should be collected.

- Where possible, plankton tows using a $30 \mu \mathrm{m}$ mesh net should be made in the vicinity of the mortality event. Plankton material should be centrifruged, and the pellet acidified with an equal volume $0.2 \mathrm{~N} \mathrm{HCl}$.

- A central repository for such samples needs to be established. The Smithsonian Institution may serve this function. Samples need to be stored and transported frozen.

- Pertinent biological data, presently obtained as part of stranding programs, should be noted. These include species, location, date, total body length, and sex. 


\begin{abstract}
APPENDIX 3
Technical Contributions

Some participants were asked to prepare short papers in their area of expertise. Some of these have already been directly incorporated into the text of this report. Others have been used only partially. Since they contain much useful information, they are appended here in their entirety. We emphasize that these contributions reflect the views of their authors and not necessarilly a concensus of the workshop participants.
\end{abstract}




\section{APPENDIX 3a}

\section{Isolation and Identification of Saxitoxin from the Atlantic Mackerel, Scomber scombrus L.}

Yuzuru Shimizu, Claudia K. Walker, and Ronghua Wang. Department of Pharmacognosy and Environmental Health Sciences, College of Pharmacy, The University of Rhode Island, Kingston, RI 02881

In November, 1987, a dozen humpback whales were found dead on the beaches of Cape Cod. The investigation of the deaths of the whales has been conducted by a team of specialists assembled by the New England Aquarium and the Woods Hole Oceanographic Institution. The test of the whale stomach contents pointed to mackerel as the possible culprit. At the request of the group and also the State of Rhode Island Health Department, we undertook the isolation of the toxic principle in the mackerel caught in Rhode Island water.

\section{Experimental Section}

Isolation

About $40 \mathrm{~kg}$ of mackerel caught off Block Island, RI, in December, 1987 were opened, and their livers were taken out. The livers $(300 \mathrm{~g}$ ) were homogenized in $900 \mathrm{ml} 0.1 \mathrm{~N} \mathrm{HCL}$ and centrifuged. The supernatant was examined for mouse toxicity according to the standard procedure. Toxicity of 2 mouse units per gram (total ca. 600 mouse units) was detected. The death symptoms in mice were identical with those of paralytic shellfish poisoning or tetrodotoxin.

The supernatant was treated with $400 \mathrm{ml}$ of active charcoal in water, and the charcoal was washed with distilled water and extracted with $100 \mathrm{ml}$ of methanol. The methanol extract was evaporated to an oily residue (ca. 400 mouse units). The residue was then dissolved in distilled water, and after the $\mathrm{pH}$ was adjusted to 7.0 , charged on a freshly prepared Biogel P-2 column (300 ml). The column was first washed with distilled water $(1 \mathrm{l})$, and then washed with $0.05 \mathrm{~N}$ acetic acid (1 1). The evaporation of the acid solution eluate gave a small amount of residue, which contained a total of 147 mouse units of the toxin. TLC examination of the fraction indicated the presence of saxitoxin besides a large amount of impurities. The fraction was further purified on a 
Biogel column $(90 \mathrm{ml})$. The column was washed with distilled water $(100 \mathrm{ml})$, and then with 0.5 $\mathrm{N}$ acetic acid solution. Each fraction was collected and checked by TLC. The fractions which showed saxitoxin spots on TLC were combined, evaporated and used for the following identification.

Identification

\section{TLC}

Solvent systems: Pyridine: ethyl acetate: $\mathrm{H}_{2} \mathrm{O}$ : acetic acid 25:9:7:5 Plates: Art 5631, HPTLC, Fertigplatten Kieselgel G. and Whatman HP-K High Performance Gel. Both sample and standard saxitoxin gave identical $\mathrm{Rf}$ and fluorescent spots upon spraying of $1 \% \mathrm{H}_{2} \mathrm{O}$ and heating.

\section{Electrophoresis}

Electrolyte buffer system: $0.08 \mathrm{M}$ Tris acidified to $\mathrm{pH} 8.7$ with conc. $\mathrm{HCI} .2 .5 \times 18 \mathrm{~cm}$ cellulose acetate membrane strips (Schleicher and Schuel \#2500). $200 \mathrm{v}, 0.5 \mathrm{~mA}$. Both sample and saxitoxin showed an identical mobility and co-migrated.

\section{Bioassay with Cultured Mouse Neuroblastoma Cells (Kogure's Method)}

Both pure sample and crude fractions prevented the rounding and death of the blastoma cells caused by veratridine. The action is typical of sodium channel blockers such as saxitoxin, gonyautoxins and tetrodotoxin.

\section{Discussion}

There is no question that the mackerel livers contained saxitoxin as a toxic component. The less than $100 \%$ recovery rate of the purified toxin $(25 \%)$ precludes a definitive conclusion if saxitoxin was the only toxin in the mackerels. However, a poor recovery is not unusual for a dilute sample with overwhelming impurities. The isolation was also done with a different batch of mackerel using Amberlite IRC-50 purification at the second step. The outcome was similar (150 mouse units of saxitoxin from 800 mouse units).

If indeed the sample contained only saxitoxin, it differed considerably from other PSP samples, which normally contain gonyautoxins, neosaxitoxins and other sulfated toxins as major 
constituents. The only exception is Alaska butter clam. This also makes it difficult to assign the east coast Gonyaulax as the source of the toxin. Most strains of the organism contain saxitoxin only as a rather minor component. Unless substantial bioconversions occur in the mackerel or its prey, the other toxins should become the major constituents. There are other findings which also cast a serious doubt on the theory that dinoflagellate blooms are the source of toxin. We have been analyzing mackerel samples caught at different times and places. Interestingly, all the samples of S. scombrus analyzed have shown almost identical levels of toxicity (ca. 2 mouse units/g liver). They include a frozen sample caught off New Jersey in April, 1987 (from Dr. L. Buckley, NMFS) and several samples caught in December, 1988. The mackerel's prey, sand lance, Ammodytes americanus, from New England waters did not show toxicity. Two Pacific specimens of $S$. japonica caught in Japan were completely devoid of the toxicity. These findings seem to point to an endogenous factor specific to the species as the origin of the toxin. We have been examining the toxin production by microorganisms isolated from the mackerel livers, but have not reached any conclusion.

This research was supported by NIH grants, GM28754 and GM24425. 


\section{APPENDIX 3b}

\section{Identification of Paralytic Shellfish Toxins in Mackerel from Southwest}

Bay of Fundy, Canada*

K. Haya, J. L. Martin, B. A. Waiwood, L. E. Burridge, J. Hungerford* and V. Zitko. Department of Fisheries and Oceans, Biological Station, St. Andrews, N.B., EOG 2X0, Canada. *Department of Human Services, Food and Drug Administration, Seattle, WA 98174, U.S.A.

During July to September 1988, Atlantic mackerel, Scomber scombrus, were sampled from 10 locations in the Southwest Bay of Fundy, New Brunswick, Canada. Intestines and livers were extracted by the AOAC procedure for paralytic shellfish toxins. Intraperitoneal injections of the liver extracts were lethal to mice and the observed symptoms were typical of paralytic shellfish poisoning (PSP). Toxin concentrations ranged from 40 to $209 \mu \mathrm{g}$ saxitoxin (STX) equivalents per $100 \mathrm{~g}$ of liver. Intestines sampled from mackerel with the most toxic liver extracts had toxin concentrations corresponding to $57 \mu \mathrm{g}$ STX equivalents per $100 \mathrm{~g}$ of intestines. None of the other extracts from intestines were lethal to mice.

Analysis of water samples collected during the same period indicated that a small bloom of Gonyaulax excavata occurred mid-to late July. Highest concentrations of G. excavata cells ( $7.4 \mathrm{x}$ $10^{3}$ cells/L) were observed in surface waters from an indicator sampling station at Head Harbour in the Bay of Fundy. Another sampling site located at Deadman's Harbour had a maximum of $4.8 \mathrm{x}$ $10^{3}$ cells/L observed during mid-July with cell numbers decreasing to zero by mid-August. During the same period and at the same site, the toxin concentrations in mackerel livers sampled decreased from 209 to $65 \mu \mathrm{g}$ STX equivalents per $100 \mathrm{~g}$ of liver.

Some of the tissue extracts from mackerel were analyzed by HPLC. Only B2, GTX II, GTX III, neosaxitoxin and saxitoxin were detected in varying relative amounts. Since the HPLC technique is more sensitive than the mouse bioassay, toxins were detected in more than one intestinal extract. The highest concentration of toxins in the intestines was $26 \mu \mathrm{g}$ STX equivalents 
per $100 \mathrm{~g}$. In general, saxitoxin was the major toxin in the livers whereas GTX II and GTX III were the major toxins in the intestines.

*Abstract of paper to be published in : Toxic Marine Phytoplankton. Proceedings of the 4th International Conference on Toxic Marine Phytoplankton. Graneli, E., D. M. Anderson, L. Edler and B. Sundstrom (eds.) Elsevier, NY. 1989. 


\section{APPENDIX 3c \\ Brevetoxin Analysis \\ Daniel G. Baden, Ph. D. Rosenstiel School of Marine and Atmospheric Science, University of Miami}

Introduction

Brevetoxins are potent polyether neurotoxins produced by Florida's red tide dinoflagellate Ptychodiscus brevis. These toxins interact in a specific manner with site 5 associated with voltage-sensitive sodium channels [1]. Binding of brevetoxins to this specific locus results in repetitive discharge of nerves resulting in neurotransmitter depletion in nerve termini [2], contractile paralysis of peripheral muscles [3], and death due to respiratory arrest [4]. The principal environmental consequences of Florida red tides are fish kills, neurotoxic shellfish poisoning, and human respiratory difficulties resulting from exposure to seaspray containing lysed P. brevis cells [5].

Evidence for toxicological consequences other than those listed above are not abundant. However, circumstantial evidence implicating brevetoxins and Florida red tide in manatee deaths was complied in 1982-1983. The unusual mass lethalities of 41 West Indian manatees (Trichechus manatus ) occurred in Lee County, Florida in February, March, and April 1982. Gross necropsy of moribund specimens revealed full stomachs, indicating recent feeding and, hence, assumed health. Atypical findings were: watery consistency of the contents of the cecum and or large intestine; hemorrhage or congestion of the brain; and the presence of ascidians in the G.I. tract. The former two observations are consistent with muscarinic stimulants and hemolytic agents, both of which are properties or characteristics of brevetoxins. The latter observation of ascidians in stomach contents is consistent with biotoxin accumulation via ascidian filter-feeding of toxic dinoflagellates and subsequent manatee transvection via inadvertent uptake during grazing on seagrasses. Subsequent demonstration of brevetoxins in ascidians from the area, and historical data which placed a red tide bloom in the area prior to the deaths, both indicate a positive correlation between manatee deaths and red tide brevetoxins [6]. 
This past year, a major $P$. brevis red tide bloom occurred off the coast of Texas and required the closing of shellfish beds for a number of months. This, according to most, was the most severe red tide experienced in Texas in recent years. Also last year, a pre-formed Florida red tide was swept out of the Gulf of Mexico by the Gulf loop current, and was entrained up the eastern coast of the United States to North Carolina, where it was maintained and continued to proliferate. The bloom was recognized in North Carolina in late October, toxic shellfish were identified a few days later, and the bloom continued until early March 1988. It is the presence of this bloom on the eastern coast of the U.S., coupled with observed dolphin deaths, which prompted an evaluation of dolphin food sources for potential brevetoxin accumulation [7].

$\underline{\text { Rationale }}$

Three questions require investigation: (1) Can $P$. brevis toxins accumulate in the food sources of dolphins?; (2) If the answer to (1) is yes, which toxins accumulate and how much is present; and (3) Are brevetoxins present in dolphin tissues? In order for brevetoxins to be transvected to dolphins, a food chain progression needs verification. The food chain hypothesis requires demonstration of brevetoxins in stomach contents and tissues of moribund dolphins, and also requires demonstration of brevetoxins in food supplies of the dolphins.

Brevetoxins in Stomach Contents of Dolphins

Can $P$. brevis toxins accumulate in the food sources of dolphins? We began by examining . stomach contents of dead dolphins for the type of fish species and for toxicity of identifiable fish in the stomach contents. Stomach content samples were both small in mass and in number. Of those preliminary observations made, one specimen each of menhaden and weakfish were examined in detail. We treated each of the two samples with 1 volume of chloroform and extracted in a Virtis tissuemizer until homogeneous. The slurry was filtered by suction, the filtrate was flashevaporated, redissolved in minimal methanol, and the methanol solution was tested for toxicity using Gambusia fish bioassay. Both samples were toxic, and initial observations indicated that the menhaden sample was more toxic than was the weakfish. However, both samples were 
obtained from the same stomach contents and we anticipated considerable cross-contamination in the two fish samples.

Further purification using silica gel thin-layer chromatography (ethyl acetate/petroleum ether solvent, 70/30), followed by visualization of the developed plate under ultraviolet light, yielded several uv absorbing bands, each of which was scraped from the plate, extracted with acetone and methanol, reduced in volume using a stream of nitrogen, and bioassayed using Gambusia fish. Each fish sample was again demonstrated to be toxic, and from the observed migration on thin-layer plates, likely was brevetoxin(s).

To confirm the presence of, and quantify brevetoxins in the samples, the remaining extract in each case was separated using HPLC (C-18 reverse phase, $85 \%$ isocratic methanol, uv detection at $215 \mathrm{~nm}$ ) and compared to standard brevetoxins. The results are indicated in Table 1. The authenticity of the peaks obtained from HPLC was further ascertained by co-migration, i.e. authentic brevetoxins were mixed with fish extract and were injected together on the HPLC. Elution as a single peak affirms the identical nature of the sample and the standard.

Brevetoxin in Fresh Fish

Upon demonstration of toxins in fish samples from stomach contents, we proceeded to examination of fresh fishes for brevetoxins in viscera, and if positive, in flesh. Samples of freshcaught fish were provided by the Florida Department of Natural Resources and were transported to Miami from Vero Beach. Individual specimens were eviscerated in preparation for a two-stage evaluation. Viscera were used fresh, and flesh samples were flash frozen and held until assay. (Flesh samples were subsequently found to be not-toxic).

Using similar protocols for extraction as have already been described, we homogenized viscera with solvent, filtered, and retained the filtrate. The filtrate was reduced in volume in each case and each was subjected to Gambusia bioassay. These results are indicated in Table 2. 
TABLE 1. HPLC detection of brevetoxins in stomach contents.

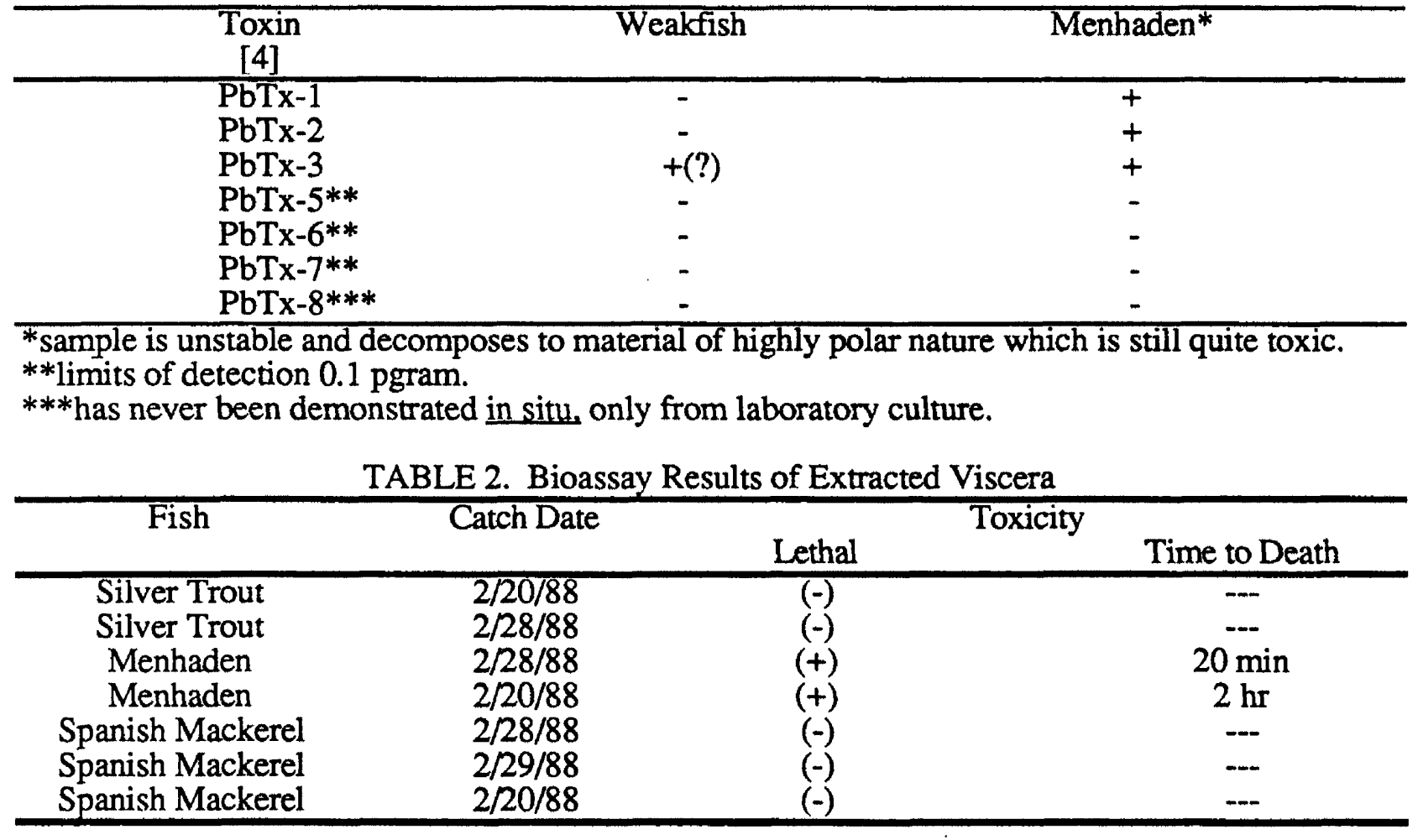

Menhaden viscera were subjected to purification procedures appropriate for brevetoxins which included in sequence: silica gel dry column chromatography using $\mathrm{CHCl}_{3} / \mathrm{MeOH} / \mathrm{HAc}$ (100:10:1) as eluent; ethyl acetate/petroleum ether (70:30) silica gel preparative thin-layer chromatography; and high performance $\mathrm{C}-18$ reverse phase liquid chromatography using isocratic $85 \%$ aqueous methanol as solvent.

A toxic fraction isolated from menhaden viscera was shown to contain both $\mathrm{PbTx}-2$ and $\mathrm{PbTx}-3$, as adjudged by lethality in Gambusia bioassay and $\mathrm{R}_{\mathbf{f}}$ in TLC. HPLC migration and lethality confirmed the likelihood of brevetoxins in the samples. Menhaden $\mathrm{PbTx}-2$ was purified to homogeneity using HPLC, and was mixed with equimolar authentic PbTx-2. HPLC of the mixture indicated a single peak migration, indicating the homogeneity of the mixed sample, i.e. the likelihood that the toxin isolated from menhaden viscera was indeed brevetoxin $\mathrm{PbTx}-2$. 


\section{Brevetoxins in Dolphin Liver Samples}

Thirty-four samples of dolphin liver were submitted for analysis, identified by number

only. About one-half were control samples. The samples were individually treated using identical protocols: frozen specimens were dehydrated by steeping in 2 volumes of anhydrous acetone for 10 hours, followed by vacuum filtration; dehydrated samples were homogenized twice in chloroform solvent, and the solvent removed by filtration; acetone and chloroform filtrates were combined and the residues discarded; filtrates were flash-evaporated, resuspended in $20-25 \mathrm{~mL}$ 90\% aqueous methanol, and solvent partitioned between methanol and petroleum ether; methanol fractions were adsorbed to dry silica gel and were used for flash chromatography employing 2 volumes of anhydrous acetone.

Samples were rechromatographed on dry columns using $100 \mathrm{~mL} \mathrm{CHCl} / 3$ methanol/acetic acid (100:10:1) and eluted samples were flash-evaporated. Two sequential preparative silica gel TLCs were performed, first using acetone/petroleum ether (30:70) and the second plate employing 70:30 of the same solvent mixture. All fractions were bioassayed at each step in the purification scheme, terminating purifications when, and if, toxicity ceased to be evident.

Samples were finally evaluated using reverse phase HPLC and detecting eluted materials at $215 \mathrm{~nm}$. Concentrations and identity of individual brevetoxins were determined by peak height, retention time, and comigration using brevetoxin standards. Fourier transform infrared spectrometry was performed on extracts of WAM-280 against authentic brevetoxin as further proof that the isolated toxins were brevetoxins.

Twenty-six of the 34 samples submitted for analysis were negative for brevetoxins; eight tested positive through the entire evaluation protocol. Of the twenty six negative samples, 17 were later revealed to have been control samples taken from captive animals, animals out of the geographic range of the incident, or animals not within the time sequence of the event. Seven additional samples were toxic throughout the entire protocol, but could not be correlated with brevetoxins in HPLC and were thus denoted "negative" with respect to the study. 
The remaining samples contained between $0.083-15.82 \mu \mathrm{g}$ toxin/gram of original liver sample. Correlations of geographic area versus toxin content are treated elsewhere in this conference.

Conclusions

It is our conclusion that, under very specialized circumstances, brevetoxins can: (1) appear in food sources of dolphins; (2) be transvected through tainted food sources to predatory species like dolphins; and, (3) accumulate in dolphin liver in surprizingly high concentrations.

\section{References}

[1] Poli, M. A., T. J. Mende, D. G. Baden (1986) Molec. Pharmacol. 30:129-135.

[2] Huang, J. M. C., C. H. Wu, D. G. Baden (1984) J. Pharmacol. Exp. Ther. 229:615-621.

[3] Baden, D. G., G. Bikhazi, S. Decker, F. F. Foldes, I. Leung (1984) Toxicon 22:75-82.

[4] Baden, D. G., T. J. Mende (1981) Toxicon 20:457-461.

[5] Baden, D. G., T. J. Mende, G. Bikhazi, I. Leung (1982) Toxicon 20:929-932.

[6] O'Shea, T. J., G. B. Rathbun (1982) Summary Report on a Die-Off of the West Indian Manatee in Lee County, FL. Spring 1982. Sirenia Project, Denver Wildlife Research Center, 3 volumes.

[7] Steidinger, K. A. this conference. 


\section{APPENDIX 3d}

\section{Actions Necessary to Assess the Possible Impacts of Marine Biotoxins on}

Marine Mammals

Robert J. Hofman. Marine Mammal Commission, 1625 Eye St., NW, Washington, DC 20006

In the last nine years, there have been at least four cases of unusual marine mammal mortalities that were, or may have been, caused by marine mammals eating organisms containing biotoxins of marine origin. These were: (1) the mass mortality of Hawaiian monk seals (Monachus schauinslandi ) on Laysan Island in 1980 thought to be caused by ciguatoxin poisoning (Gilmartin, 1987); (2) the die-off of manatees (Trichechus manatus ) in the area around Fort Myers, Florida, in 1982 thought to be caused by manatees eating tunicates containing brevetoxins from a "red tide" (O'Shea and Rathbun, 1982); (3) the mass mortality of bottlenose dolphins (Tursiops truncatus) along the mid- and south-Atlantic coasts of United States in 1987-88 thought to have been caused or initiated by dolphins eating fish containing brevetoxin from a red tide (Geraci, 1989); and (4) the die-off of humpback whales in Cape Cod Bay in December 1987 thought to be caused by eating mackerel containing saxitoxin from a phytoplankton bloom further north (Geraci et al., in press). In addition, there is empirical evidence (Kvitek, et al., in prep.) suggesting that paralytic shellfish poisoning may be a factor influencing the distribution of sea otters (Enhydra lutris ) in Alaska.

Although there is good circumstantial and, in some cases, empirical evidence to support the view that the referenced monk seal and manatee mortalities, and some aspects of sea otter distribution in Alaska, are attributable to biotoxin poisoning, there are questions as to whether the referenced dolphin and humpback whale mortalities were in fact caused or initiated by biotoxin poisoning. That is, it has not been demonstrated unequivocally that the dolphins and humpback whales that died could have been exposed to biotoxins and/or that the exposure levels would have had the observed effects. Also, if saxitoxin and brevetoxin poisoning were in fact the cause of the observed humpback whale and bottlenose dolphin mortalities, one wonders why such mortalities 
have not been observed in the past. This in turn raises the question as to whether there has been a change in the distribution, frequency, size, or dynamics of biotoxin-producing phytoplankton blooms (due to natural or anthropogenic factors) which are resulting in greater numbers of marine mammals being at risk of biotoxin poisoning.

To resolve uncertainties concerning the pathways, risks, and effects of possible biotoxin poisoning, at least three things must be done. First, samples form representative species of fish and marine mammals that inhabit areas where they possibly can be exposed to biotoxin-producing organisms should be collected periodically for several years and analyzed to determine the likely frequency and levels of exposure to biotoxins. Samples of fish for these analyses probably can best be obtained by randomly sampling commercial fish catches in and near areas where biotoxinproducing plankton blooms are known to occur. Marine mammal samples probably can best be obtained from animals taken incidentally during commercial fishing operations and/or from animals that are found washed up on beaches in or near areas where biotoxin-producing phytoplankton blooms are known or are thought to occur.

The second task is to establish programs to monitor (a) the information and dispersal of biotoxin-producing phytoplankton blooms, and factors, such as water temperature and currents, responsible for formation, transport and dispersal of such blooms, and (b) the levels of biotoxins present in fish and marine mammal species most likely to be exposed to potentially hazardous biotoxins. These are critical tasks and presumably will be major topics of discussion at this workshop.

The two preceding tasks will provide information necessary to determine the possible pathways, frequency, and quantities of biotoxins to which marine mammals may be exposed. They may not indicate how different types and levels of biotoxin exposure affect various species of fish or marine mammals. To determine probable cause-effect relationships, it may be necessary to conduct controlled feeding experiments to document how representative fish and marine mammal species respond to and are affected by exposure to different types and levels of biotoxins. In this 
context, it is important to recognize that certain types or levels of biotoxin poisoning may affect the behavior of intoxicated fish in ways that would make them more enticing or vulnerable to predation by marine mammals and thus increase the probability of marine mammals consuming intoxicated fish.

Bibliography

Gilmartin, W. G. 1987. Hawaiian monk seal die-off response plan, a workshop report, 2 April 1980, San Diego, California. NMFS Administrative Report H-87-19.

Geraci, J. R. 1989. Clinical investigation of the 1987-88 mass mortality of bottlenose dolphins along the U.S. central and south Atlantic coasts. Final report to the NMFS, ONR, and MMC.

Geraci, J. R., D. M. Anderson, R. J. Timperi, G. A. Early, J. H. Prescott, and C. A. Mayo. Humpback whales fatally poisoned by dinoflagellate toxins. Can. J. Fish. Aquat. Sci. (in press).

O'Shea, T. J. and G. B. Rathbun. 1982. Summary report on the die-off of the West Indian manatee (Trichechus manatus) in Lee County, Florida. Spring 1982. Sirenia Project. Denver Wild. Res. Center. Gainesville, Field Station, 412 N. E. 16th Ave. Gainesville, FL. 32601. 3 Vols. unpublished.

Kvitek, R. G., A. R. DeGange and M. K. Beitler. Paralytic shellfish toxins mediate sea otter food preferred and distribution, and therefore marine community structure. (in preparation). 


\section{APPENDIX 3e}

Implications of 1986-87 Ptychodiscus brevis Red Tide and 1987-88 Mass Bottlenose Dolphin Mortalities

Karen A. Steidinger. Florida Marine Research Institute, Department of Natural Resources, 100 Eighth Ave. S. E., St. Petersburg, FL 33701

Introduction

Between June 1987 and March 1988, over 740 bottlenose dolphins, mainly of the midAtlantic coastal stock, were stranded between New Jersey and Florida ${ }^{1}$. The strandings of dead or dying dolphins started in June in their summer grounds between North Carolina and New Jersey. Most subsequent strandings were coincident with the southerly migration of Tursiops in coastal waters. Hersh ${ }^{2}$ documented the seasonal occurrences of coastal Tursiops truncatus as the following: 1) North Carolina to New Jersey in summer, 2) Carolinas to Florida in fall, with a concentration in northeast and central Florida coastal waters in winter, and 3) a northerly migration starting in spring.

In a report entitled "Clinical investigation of the 1987-88 mass mortality of bottlenose dolphins along the U.S. Central and South Atlantic Coast," Geraci ${ }^{3}$ synthesized and reported data and information gathered by a team of investigators. Geraci, in his introduction, stated "This report describes how the investigative process evolved, and the evidence implicating a biological toxin as the proximate cause. The dolphins apparently were poisoned by brevetoxin, a neurotoxin produced by the dinoflagellate Ptychodiscus brevis, Florida's red tide organism. The dolphins were eventually infected with a host of bacterial and viral pathogens which produced an array of beguiling clinical signs." Liver tissue from seventeen freshly dead dolphins (August 1987 to February 1988) were tested for the presence of brevetoxin(s); eight livers contained brevetoxin as determined by HPLC procedures and brevetoxin standards. In addition, one liver extract positive for brevetoxin was tested using Fourier transform infrared transmission spectrometry, which verified the presence of PbTx-2. All other dolphin liver tissues used as controls (17) were negative for brevetoxin. 
Brevetoxin was also found in the viscera of menhaden, Brevoortia sp., taken from the stomach of one stranded dolphin off Florida; however, liver tissue from the dolphin as well as other fish in the stomach contents, i. e., weakfish, did not contain brevetoxin. Also, fresh-caught yellowfin menhaden, Brevoortia smithi, collected off Vero Beach, Florida, in February 1988 contained brevetoxin in the viscera. All of the testing for brevetoxin was done in the laboratory of Dr. Daniel Baden, University of Miami. The above data demonstrate two important points: 1) brevetoxin can be accumulated in planktivorous fishes, and 2) bottenose dolphin can encounter brevetoxin, presumably through the food chain.

\section{Ptychodiscus brevis Red Tides and Marine Mammal Mortalities}

Red tides are natural phenomena that have occurred in the world's seas since biblical days (Exodus, 7:20-21). Such phenomena are usually caused by high concentrations of microalgae, most often flagellates, in the water column. Although many red tides are not red and are not associated with tides, they can be visibly detected when sea surface discoloration is caused by high concentrations of organisms or when dead fish are observed. Other signs of red tides are indirectly revealed by human illness and mortality from eating toxic seafood, usually filter-feeding bivalve mollusks.

Florida red tides caused by Ptychodiscus brevis, a dinoflagellate, can be associated with discolored seawater, shellfish toxicity (Neurotoxic Shellfish Poisoning), fish kills, and a toxic seaspray aerosol that can irritate the eyes, nose, mouth, and throat of people in the immediate vicinity of the jet spray4,5. Ptychodiscus brevis is a gymnodinioid of restricted Atlantic distribution, but with conspecific representatives in the Pacific. It is known from the Gulf of Mexico (Florida, Texas, and Mexico), the North Atlantic (Florida, North Carolina, and South Carolina), the Gulf of Stream, and possibly the Caribbean. P. brevis red tides in the eastern Gulf of Mexico and southeastern U.S. waters originate off west central Florida about 10 to $40 \mathrm{mi}$ offshore, and initiation of red tides is associated with oceanic intrusions onto the shelf 6 . They can be entrained and transported from the west coast of Florida to the east coast by Loop Current 
waters, which enter the Florida Straits as the Florida Current and eventually merge with the northerly moving Gulf Stream. Such transport occurred in the fall months of $1972^{6}, 1977^{6}$, $1980^{6}, 1983^{7}$, and $1987^{8}$.

Ptychodiscus brevis red tides are typically seasonal in that they usually begin off the west coast of Florida in late summer/early fall and last until or through January. It takes about four weeks for an offshore red tide to develop concentrations that can cause fish kills 9 . In addition to transport of blooms around the Florida peninsula, Lackey 10 and Marshall11,12 have reported this species in very low concentrations $\left(<2 \mathrm{ml}^{-1}\right)$ in the Gulf Stream off the southeast U.S. coast. Driftbottle releases in waters off central west Florida from 1965 to 196813 and their subsequent returns, document that surface transport from cental west coast offshore and coastal waters to Florida east coast sites can be completed in as short as 7 days and often in less than one month. Also, returns of bottles from North Carolina and South Carolina in summer and fall were in as little as 31 days during that period. Therefore, $P$. brevis, a flagellate that produces neurotoxins ${ }^{14}$, can occur with Atlantic coastal and offshore dolphins, but along the west coast of Florida, dolphin mortalities coincident with red tide events (some lasting up to eleven months) are few 15,16 and are not more numerous than dolphin mortalities in the Gulf of Mexico, e.g., 1986 and 198717.

The only previous coincidental data implicating $P$. brevis blooms in marine mammal mortalities concerns the West Indian manatee (Trichechus manatus latirotris ) mortalities in Charlotte Harbor, Florida, in 198218. In this outbreak, red tide was thought to have been introduced through the food chain and was noted to cause behavioral changes and stress. An unusual set of circumstances existed in that live $P$. brevis cells are usually limited to waters of salinities $>24 \%$, and manatees usually feed in the upper reaches of the estuary at lower salinities. In 1982, however, there was a drought, and manatees were feeding on seagrasses in higher salinity areas. In 1982 there was also an abundance of tunicates (e.g., Mogula spp.) in these seagrass beds, and $M$. occidentalis and $M$. manhattensis were found in the stomachs of dead manatees. Tunicates are filter feeders and can concentrate biotoxins from phytoplankton. In 
Japan, tunicates have been documented to accumulate saxitoxin, a water-soluble dinoflagellate toxin, and become toxic for human consumption ${ }^{19}$. Baden analyzed tunicates collected from Charlotte Harbor after the manatee mortalities and found toxic compounds but could not verify the presence of $\mathrm{PbTx}$ in tunicate tissue ${ }^{18}$.

Because bottlenose dolphins from the 1987-88 mortalities contained brevetoxin ( 83 to $15,820 \mathrm{ng} / \mathrm{g}$ liver tissue) ${ }^{3}$, it is probable that they came in contact with the toxic organisms directly in the water column, or indirectly through the food chain. Direct contact is unlikely to cause accumulation of toxins in liver tissue and has apparently not caused mass mortalities of dolphins off the west coast of Florida, where $P$. brevis red tides can be intensive (concentrations of $>180,000$ cells ml$^{-1}$ ) and of long duration. Toxicity through the food chain is much more plausible because dolphins consume fish whole, and if prey items have toxic viscera, dolphins could possibly be compromised to the point of nonfeeding, modification of behavior and orientation, and/or immunoincompetency. Several synergistic factors could have been involved in the 1987-88 mortalities, beyond biotoxins, in physiological stress and debilitation.

Dolphins are not the only pelagic coastal animals that have a seasonal coastal migration pattern between Florida and the northeast U.S. coast. Several of their prey species have the same distribution and occurrence; this has been revealed by tag-and recapture studies and data on seasonal fishery landings by area. For example, Spanish mackerel (Atlantic stock), a prey item for dolphins, are concentrated off Florida's east coast in winter and their most southward extension is the Florida Keys, where Gulf of Mexico and Atlantic waters meet. Spanish mackerel, Scomberomorus maculatus, are landed in Florida in winter, in the Carolinas in April, in Chesapeake Bay in May, and in Rhode Island in July20. Dolphins also feed on menhaden and other clupeid or herring-like fishes. Atlantic menhaden (Brevoortia tyrannus) has a similar migratory pattern. Atlantic menhaden tagged in northeast Florida nearshore waters in April were recaptured in New Jersey in July 21 . These distribution and migratory patterns are probably associated with water temperature changes and other cues, e.g., availability of food. Although the 
toxic menhaden from dolphin stomach contents was not identified to species and the live menhaden caught off Vero Beach, Florida, was thought to be $B$. smithi, all menhaden are planktivorous. Therefore, $B$. tyrannus, Atlantic menhaden, could conceivably be a vector as well.

It would appear that predator and prey are traveling the same routes at approximately the same times, or they at least occur in the same area at the same time. It is not uncommon in nature for predators to move from one feeding ground to another based on seasonal food availability, nor is it uncommon for predators to co-migrate with prey. Spanish mackerel, a food item of dolphins, is also a predator of menhaden. These mackerel are a siginificant predator of large schools of clupeid fishes in surface coastal waters of the U.S.20,22.

Coastal dolphins feeding on coastal Spanish mackerel that have fed on coastal menhaden, or coastal dolphins feeding directly on herring-like fishes, could become ill and debilitated if their prey had biomagnified biologically active compounds, such as dinoflagellate toxins. The question then becomes, how did the prey become toxic.

Historical data on distribution patterns puts potentially toxic clupeids and a predator, Spanish mackerel, off the Carolina coasts at the time of a Ptychodiscus brevis bloom in coastal waters (October-December 1987) ${ }^{8}$. Dolphins were dying off the Carolinas in June, August, September, October, November, and December. The above scenario would not account for deaths off the Carolinas prior to mid-October, when a warm water intrusion containing $P$. brevis caused a red tide in North Carolina, unless prey fishes were toxic prior to the North Carolina event. The question then becomes, "Could prey items, such as clupeid fishes and Spanish mackerel become toxic in south Florida waters in winter or spring of 1987?" To address the question of toxicity in fishes, we first have to ask if there was a P. brevis red tide in south Florida in winter/spring 1987. Also, could it have been transported to the east coast of Florida in winter or spring, February to May, or did toxic prey migrate from the Gulf to the east coast of Florida.

A 1986 Florida west coast red tide, that was first detected in September continued into 198723. In January 1987, it was offshore in the Tampa Bay area and inshore in Charlotte and Lee 
Counties, in southwest Florida. By February, inshore $P$. brevis counts were increasing again and Florida Marine Research Institute staff, with the aid of the U.S. Coast Guard, sampled offshore waters on February 17; at 15 miles off Stump Pass, surface counts for $P$. brevis were $47 \mathrm{ml}^{-1}$ and at 15 miles off Sanibel, cell counts were $3.7 \mathrm{ml}^{-1}$. On March 6 at approximately the same distance offshore, cell counts were $1 \mathrm{ml}^{-1}$. However, on April 23, one fisherman reported dead fish along the $30 \mathrm{fm}$ line from the Florida Keys to just south of Tampa Bay, about 70 miles offshore. On April 27, another fisherman reported surface water discoloration along the same location. On a May 12-15 offshore cruise between Cedar Key and the Dry Tortugas, water samples, from various depths out to $180 \mathrm{mi}$, did not contain $P$. brevis. This information puts $P$. brevis at 15 miles off of a known transport point for Gulf waters to the east coast in mid-February and gives anecdotal evidence of a bloom in the Florida Keys. Drift bottles, from releases off southwest Florida in winter and early spring during 1965-1967, were recovered from Florida east coast locations in as little as 18 days; several releases made it to Fort Pierce, Florida in 25 days ${ }^{13}$. This suggests that $P$. brevis could have been along the Florida east coast in March and April of 1987.

Having established a plausible mechanism of intoxication, via the food chain, and having demonstrated the mechanism to put $P$. brevis in the same place and at the same time, as east coast clupeids and Spanish mackerel, the next question is why didn't $P$. brevis, which is known to kill fish, kill the clupeid fish or Spanish mackerel. For fishes to accumulate dinoflagellate neurotoxins rather than succumb from respiratory failure probably means that they were exposed to low concentrations in the water column, e.g. 5-50 ml-1 and less than $100 \mathrm{ml}^{-1}$ to $1000 \mathrm{ml}^{-1}$ since these concentrations are known to kill certain fishes in acute exposures. This is not an uncommon lower level (5-50 cells ml-1) in Florida Current/Gulf Stream waters from Miami to West Palm Beach when $P$. brevis is transported, e.g., in 1972 and 1977. The unusual event was that transport would have occurred in February to May. Southwest Florida does not usually have red tides at that time of the year. All documented $P$. brevis red tide events (toxic aerosol, fish kills, toxic shellfish, etc.) off the southeast U.S. coast occurred in fall $(1972,1977,1980,1983,1987)$. 
What this means is that $P$. brevis in low concentrations probably is more common in the Gulf Stream than previously thought and at all seasons.

It should be emphasized that although fishes through predator-prey interactions could become toxic, the toxicity (analyses to date) is contained in the viscera and not the flesh. Cultural customs in the U.S. are such that fishes for human consumption are typically gutted and filleted; they are usually not consumed whole. Dolphins consume fish whole. One fish that can be indirectly consumed whole by humans or domestic animals is menhaden, i.e. fish meal. Geraci's report ${ }^{3}$ points out the necessity to test menhaden products if they are potentially collected form a $P$. brevis red tide area for supplements to domestic animal feed or human food. No human illness, with the typical brevetoxin symptoms, from eating any fish collected in red tide waters has ever been reported or documented, and red tides or their effects have been documented in Florida since the mid 1800s. The Bonaventura and Bonaventura article, which Geraci ${ }^{3}$ cites as unusual human intoxications from eating toxic fish caught off Carolina in summer of 1987 , is related to ciguatoxic fish fillets.

The 1987-88 bottlenose dolphin mortalities and the 1982 manatee deaths in Charlotte Harbor suggest that the manatee deaths and the dolphin deaths were rare events due to unusual timing and environmental conditions. If not, manatees and dolphins in waters from Cedar Key to the Ten Thousand Islands would be continually dying during west coast red tides, which have occurred for varying durations, at varying coastal locations, and at varying concentrations for many years. One protection for such populations is that mid and upper reaches of west coast bay systems, because of lower salinities in these areas, do not usually support red tides once they are transported inshore from their offshore origin. The local dolphin population could find relief in these areas, by avoiding many of the effects of red tides. There have only been a few reported dolphin strandings and deaths during west coast Florida red tides and cause of death was not investigated. 
It is possible that those dolphins from the Carolinas to Florida with brevetoxins in liver tissue were debilitated by chronic exposure to such a biotoxin. The earlier reports in 1987 of dolphin deaths off northeast states in summer do not have supporting documentation of brevetoxins in tissues and the food chain scenario for Virginia to New Jersey dolphin mortalities is only plausible speculation, based on known migratory information of coastal fish stocks.

\section{Recommended Research}

Obviously, further research is needed to determine the extent of brevetoxin(s) in fishes and stranded marine mammals, to pursue a food chain hypothesis. Also, acute red tide events can debilitate or kill birds that feed on toxic shellfish ${ }^{24}$ or possibly whole toxic fish, which means that $P$. brevis cell concentrations above background levels have the potential to impact vertebrates that feed on toxic prey, either through acute or chronic exposure. This dinoflagellate, at concentrations

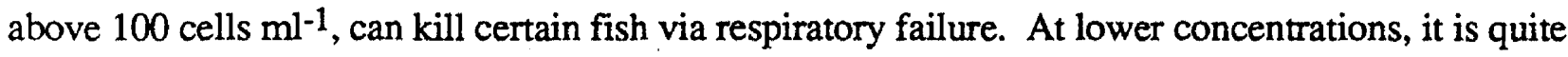
possible that planktivorous fishes can bioaccumulate brevetoxins and thus impact higher predators.

Future research should address the following points:

- Determine the effects of chronic exposure to sublethal levels of brevetoxins on finfish, e.g., accumulation of toxins in viscera and rate of natural detoxification (R. Pierce, Mote Marine Laboratory, currently pursuing).

- Assess the impact of toxic prey on marine mammal diseases and mortality, e.g., stranding of dolphins, whales, and manatees, using immunocompetency tests and other available techniques.

- Determine bioaccumulation of brevetoxins through food webs. Identify whether there are potential public health problems.

- Conduct offshore sampling programs (Florida) to determine red tide initiation requirements, prepare a model for prediction, and anticipate transport to other national waters (FMRI, University of South Florida, and Mote Marine Laboratory, currently formulating). 
- Stimulate research collaborations on a national and international level to investigate worldwide toxic microalgae phenomena and possible common denominators in bloom development, toxin production, and mass mortalities.

\section{$\underline{\text { References }}$}

1. Scott, G. P., D. M. Burn and L. J. Hansen. 1988. The dolphin die-off: long-term effects and recovery of the population. Proc. Oceans '88, Baltimore, MD. pp. 819-823.

2. Hersh, S. L. 1987. Characterization and differentiation of bottlenose dolphin populations (genus Tursiops ) in the southeastern U.S. based on mortality patterns and morphometrics. Univ. of Miami, Coral Gables, Fl. Ph.D. dissertation. 213 pp.

3. Geraci, J. R. 1989. Clinical investigation of the 1987-88 mass mortality of bottlenose dolphins along the U.S. central and south Atlantic coast. Final report to National Marine Fisheries Service and U.S. Navy, Office of Naval Research and Marine Mammal Commission, April 1989.

4. Steidinger, K. A. and D. G. Baden. 1984. Toxic marine dinoflagellates, p. 201-249. In D. L. Spector (ed.) Dinoflagellates, Academic Press, Orlando.

5. Pierce, R. H. 1986. Red tide (Ptychodiscus brevis) toxin aerosols: a review. Toxicon 24: 955-966.

6. Steidinger, K. A. and K. D. Haddad. 1981. Biologic and hydrographic aspects of red tides. Bioscience 31 (11): 814-819.

7. B. S. Roberts, FMRI, reported $P$. brevis from Volusia to Brevard County waters at $1 / 2$ mile to shore in concentrations from less than detectable to $1,530 \mathrm{ml}^{-1}$ in fall, 1983 .

8. Tester, P. A., P. K. Fowler and J. T. Turner. Gulf Stream transport of the toxic red tide dinoflagellate, Ptychodiscus brevis from Florida to North Carolina. In Proceedings of Symposium on Novel Phytoplankton Blooms: Causes and Impacts of Recurrent Brown Tides and Other Unusual Blooms, October 27-28, 1988, Stony Brook, N.Y. (in press).

9. Roberts, B. S. 1979. Occurrence of Gymnodinium breve red tides along the west and east coasts of Florida during 1976 and 1977, p. 199-202. In D. L. Taylor and H. H. Seliger (eds.), Toxic Dinoflagellate Blooms, Elsevier/North Holland, Inc., N.Y.

10. Lackey, J. B. 1969. Microbiological studies in the FWPCA project area with comparisons to other subtropical and tropical areas, p. 52-85. In R. F. McAllister (ed.), Demonstration of the limitations and effects of waste disposal on an ocean shelf. Fla. Ocean Sci. Inst. Rep. AR-69-2.

11. Marshall, H. G. 1980. Phytoplankton distribution along the eastern coast of the U.S.A. Part III. Checklist of phytoplankton. Sp. Report 101. Old Dominion Univ. Res. Foundation, Norfolk, VA. 19 pp.

12. Marshall, H. G. 1982. The composition of phytoplankton within the Chesapeake plume and adjacent waters off the Virginia coast, U.S.A. Est., Coast. and Shelf Sci. 15: 29-43. 
13. Williams, J., W. F. Grey, E. B. Murphy and J. J. Crane. 1977. Drift bottle analysis of eastern Gulf of Mexico surface circulation. Mem. Hourglass Cruises. Vol. 4. 134 pp.

14. Baden, D. G. 1983. Marine food-borne toxins. Int. Rev. Cytol. 82: 99-150.

15. Steidinger, K. A., M. A. Burklew and R. M. Ingle. 1973. The effects of Gymnodinium breve toxin on estuarine animals, p. 179-202. In D. Martin and G. Padilla (eds.), Marine Pharmacognosy, Academic Press, N. Y.

16. Gunter, G., R. H. Williams, C. C. Davis and F. G. Smith. 1948. Catastrophic mass mortalities of marine animals and coincidental phytoplankton bloom on the west coast of Florida, November 1946 - August 1947. Ecol. Monog. 18: 309-324.

17. R. Pierce, Mote Marine Laboratory, Sarasota, FL, Personal Communication.

18. O'Shea, T. J. and G. B. Rathbun. 1982. Summary report on a die-off of the West Indian manatee (Trichechus manatus ) in Lee County, Florida, Spring 1982. 3 volumes. Sirenia Project Report, Gainesville, Florida.

19. Oshima, J. , T. Yasumoto, M. Kodama, T. Ogata, Y. Fukuyo, and F. Matsuura. 1982. Features of paralytic shellfish poison occurring in Tohoku District. Bull. Jpn. Soc. Sci. Fish. 48: 525-530.

20. Berrien, P. and D. Finan. 1977. Biological and fisheries data on King mackerel, Scomberomorus cavalla (Cuvier). Nat. Mar. Fish. Ser., Sandy Hook Laboratory, Highlands, New Jersey, Tech. Ser. Rep. No. 8. 42 pp.

21. Dryfoos, R. L., R. P. Cheek, and R. L. Kroger. 1973. Preliminary analyses of Atlantic menhaden, Brevoortia tryannus, migration, population structure, survival and exploitation rates, and availability as indicated from tag returns. Fishery Bulletin 71: 719-734.

22. Saloman, C. H. and S. P. Naughton. 1983. Food of Spanish mackerel, Scomberomorus maculatus, from the Gulf of Mexico and southeastern seaboard of the United States. NOAA Tech. Mem. NMFS-SEFC-128. $22 \mathrm{pp}$.

23. B. S. Roberts (FMRI, unpublished data).

24. Forrester, D. J., J. M. Gaskin, F. H. White, N. P. Thompson, J. A. Quick, Jr., G. E. Henderson, J. C. Woodard and W. D. Robertson. 1977. An epizootic of waterfowl associated with a red tide episode in Florida. Journal of Wildlife Diseases 13: 160-167. 


\section{DOCUMENT LIBRARY}

July 5, 1989

Distribution List for Technical Report Exchange

Attn: Stella Sanchez-Wade

Documents Section

Scripps Institution of Oceanography

Library, Mail Code C-075C

La Jolla, CA 92093

Hancock Library of Biology \& Oceanography

Alan Hancock Laboratory

University of Southern California

University Park

Los Angeles, CA 90089-0371

Gifts \& Exchanges

Library

Bedford Institute of Oceanography

P.O. Box 1006

Dartmouth, NS, B2Y 4A2, CANADA

Office of the International

Ice Patrol

c/o Coast Guard R \& D Center

Avery Point

Groton, CT 06340

Library

Physical Oceanographic Laboratory

Nova University

8000 N. Ocean Drive

Dania, FL 33304

NOAA/EDIS Miami Library Center

4301 Rickenbacker Causeway

Miami, FL 33149

Library

Skidaway Institute of Oceanography

P.O. Box 13687

Savannah, GA 31416

Institute of Geophysics

University of Hawaii

Library Room 252

2525 Correa Road

Honolulu, HI 96822

Library

Chesapeake Bay Institute

4800 Atwell Road

Shady Side, MD 20876

MIT Libraries

Serial Journal Room 14E-210

Cambridge, MA 02139
Director, Ralph M. Parsons Laboratory

Room 48-311

MIT

Cambridge, MA 02139

Marine Resources Information Center

Building E38-320

MrT

Cambridge, MA 02139

Library

Lamont-Doherty Geological

Observatory

Colombia University

Palisades, NY 10964

Library

Serials Department

Oregon State University

Corvallis, OR 97331

Pell Marine Science Library

University of Rhode Island

Narragansett Bay Campus

Narragansett, RI 02882

Working Collection

Texas A\&M University

Dept. of Oceanography

College Station, TX 77843

Library

Virginia Institute of Marine Science

Gloucester Point, VA 23062

Fisheries-Oceanography Library

151 Oceanography Teaching Bldg.

University of Washington

Seattle, WA 98195

Library

R.S.M.A.S.

University of Miami

4600 Rickenbacker Causeway

Miami, FL 33149

Maury Oceanographic Library

Naval Oceanographic Office

Bay St. Louis

NSTL, MS 39522-5001

Marine Sciences Collection

Mayaguez Campus Library

University of Puerto Rico

Mayagues, Puerto Rico 00708 


\begin{tabular}{|c|c|c|c|}
\hline $\begin{array}{l}\text { REPORT DOCUMENTATION } \\
\text { PAGE } \\
\end{array}$ & $\begin{array}{l}\text { 1. REPOAT NO. } \\
\text { WHOI-89-36 }\end{array}$ & 2. & 3. Reciplent's Accesesion No. \\
\hline \multirow{2}{*}{\multicolumn{3}{|c|}{$\begin{array}{l}\text { 4. Thtle and Subtitle } \\
\text { Toxic Dinoflagellates and Marine Mammal Mortalities } \\
\text { Proceedings of an Expert Consultation held at the Woods Hole Oceanographic Institution }\end{array}$}} & $\begin{array}{l}\text { 5. Raport Date } \\
\text { November, } 1989\end{array}$ \\
\hline & & & 6. \\
\hline \multicolumn{3}{|c|}{$\begin{array}{l}\text { 7. Author(s) } \\
\text { Donald M. Anderson and Alan W. White }\end{array}$} & $\begin{array}{l}\text { 8. Porforming Organization Ropt. No. } \\
\text { WHOI-89-36, CRC-89-6 }\end{array}$ \\
\hline \multirow{2}{*}{\multicolumn{3}{|c|}{$\begin{array}{l}\text { 9. Pertorming Organization Name and Addreas } \\
\text { The Woods Hole Oceanographic Institution } \\
\text { Woods Hole, Massachusetts } 02543\end{array}$}} & 10. Project/Task/Work Unit No. \\
\hline & & & $\begin{array}{l}\text { 11. Contract(C) or Grant(G) No. } \\
\text { (C) } \\
\text { (G) NA86-D-SG090 }\end{array}$ \\
\hline \multirow{2}{*}{\multicolumn{3}{|c|}{$\begin{array}{l}\text { 12. Sponsoring Organization Name and Addres: } \\
\text { NOAA, National Marine Fisheries Service, Woods Hole Oceanographic Institution } \\
\text { Coastal Research Center, Andrew W. Mellon Foundation and the Woods Hole } \\
\text { Oceanographic Institution Sea Grant Program. }\end{array}$}} & $\begin{array}{l}\text { 13. Type of Report \& Period Covered } \\
\text { Technical Report }\end{array}$ \\
\hline & & & 14. \\
\hline
\end{tabular}

This report should be cited as: Woods Hole Oceanog. Inst. Tech. Rept., WHOI-89-36 (CRC-89-6).

16. Abstract (Limit: 200 words)

On May 8 and 9, 1989, a consultation of experts was convened at the Woods Hole Oceanographic Institution to discuss the possible link between natural biotoxins and recent mass mortalities of humpback whales and bottlenose dolphins along the eastern coast of the United States. The focus was on the role of dinoflagellate toxins in these events. The objectives of the meeting were to review and assess the existing evidence and to recommend research priorities.

This report summarizes the proceedings of the consultation. The participants recommended that the information presently available has sufficient implications with respect to marine mammal mortalities, commercial fisheries, and public health to justify further investigations into the impact of dinoflagellate toxins on higher trophic levels. A series of research and monitoring programs is suggested.

17. Document Analysis Deseriptors
1. red tide
2. toxic dinoflagellates
4. seafood safety
3. marine mammals

b. Identitiers/Open-Ended Torms

c. COSATI Fiold/Group

18. Avallability Statement

Approved for publication; distribution unlimited.

\begin{tabular}{|c|}
\hline $\begin{array}{l}\text { 19. Securty Class (This Poport) } \\
\text { UNCLASSIFIED }\end{array}$ \\
\hline 20. Securthy Clase (This Pago)
\end{tabular}

21. No. of Pages 65

22. Price 